\title{
Rechtswaarborgen in een herijkte welvaartsstaat $^{\mathrm{I}}$
}

\section{Over de cruciale rol van (sociale) grondrechten in België}

\author{
Dr. Frédéric Vanneste*
}

\section{Inleiding en definitie van welvaartsstaat}

I. Het zijn verwarrende tijden in Europa. De eurocrisis bedreigt de Europese welvaart en er is geen consensus over hoe het nu verder moet. Het debat woedt volop of en in welke mate de lidstaten nog meer soevereine beslissingsmacht moeten afstaan aan de Europese Unie. Volgens sommigen moet Europa een duidelijker politiek en sociaal project worden. Anderen pleiten voor een terugplooi op de natiestaat. Zowel de 'welvaart' als de 'staat' staat onder druk. Schrijven over 'rechtswaarborgen' in een 'herijkte welvaartsstaat' op een ogenblik dat de economische welvaart vermindert en de Europese natiestaten zich existentiële vragen stellen, is aldus op het eerste gezicht geen gemakkelijke oefening. Toch zijn beide vaststellingen voor deze juridische bijdrage minder problematisch dan men zou kunnen verwachten. De vraag hoe men de welvaart kan behouden is immers vooral een economische vraag, en de vraag of men binnen een natiestaat of binnen een supranationale staat wil leven is dan weer vooral een politieke vraag. Een jurist zal zich vooral dienen af te vragen welke rechtswaarborgen er bestaan voor het individu en het collectief op een ogenblik dat de welvaartsstaat geherdefinieerd wordt door economische of politieke factoren. Of anders gezegd: welke zijn de juridische grenzen waaraan een herijking van de welvaartsstaat moet voldoen? Vooraleer deze vraag verderop te beantwoorden door eerst de rechtswaarborgen op te lijsten (2) en daarna de juridische controle daarvan te analyseren (3) (4) en (5), lijkt het cruciaal om nader stil te staan bij het begrip welvaartsstaat.

2. Het begrip welvaartsstaat definiëren is een hachelijke bezigheid. Het verwijst in elk geval niet zozeer naar een staat waarin welvaart heerst. ${ }^{2}$ Esping-Andersen stelt dat het de taak is van een welvaartsstaat om 'sociaal welzijn' (of welvaart) te

* Auditeur Raad van State, Vrijwillig wetenschappelijk medewerker KULeuven. Dit artikel is geschreven op persoonlijke titel en verbindt enkel de auteur.

I In België is het gangbaar om te verwijzen naar de 'welvaartsstaat' in plaats van de 'verzorgingsstaat'. De laatste term is misschien begripsmatig juister, maar wijkt dan weer af van het door het internationaal taalgebruik vertrouwde woordbeeld. Zie H. Deleeck, De Architectuur van de welvaartsstaat opnieuw bekeken, Leuven, Acco, 2008, 28.

2 Instituut voor Sociaal Recht, KUL, 'De Actieve Welvaarsstaat', <www.law.kuleuven.be/isr/ onderzoek/onlinerapportenbijlagen/actieve\%2owelvaartstaat.PDF >, I. 
produceren en te (her)verdelen. ${ }^{3}$ Vanuit juridisch oogpunt lijkt het vooral belangrijk om de welvaartsstaat te omschrijven als 'een staat die het op zich neemt de welvaart van de burgers te beschermen. ${ }^{4}$ De effectieve bescherming van grondrechten is daarvoor cruciaal. Deleeck omschrijft de welvaartsstaat als 'de samenlevingsvorm van sommige rijke geïndustrialiseerde landen waarbij een aantal grondrechten van de burger, met het oog op zijn materiële welvaart en de bevordering van zijn kansen tot ontplooiing, binnen een wettelijk raamwerk, effectief gewaarborgd worden. Dit alles in het raam van de parlementaire democratie, en met behoud van de vrije markteconomische productiewijze. ${ }^{5}$ De meeste auteurs zullen de sociale zekerheid een centrale rol toebedelen bij het omschrijven van de welvaartsstaat. Een welvaartsstaat beschermt echter niet alleen het recht op sociale zekerheid, zoals erkend en aanvaard in de Universele Verklaring van de Rechten van de Mens, maar in principe alle sociale en economische grondrechten van zijn burgers. Dit betekent evenwel niet dat één bepaald maatschappelijk model wordt opgedrongen. Er bestaan verschillende types welvaartsstaten (het sociaal-democratische, ${ }^{6}$ het conservatief-corporatistische ${ }^{7}$ en het liberale ${ }^{8}$ model) die het gevolg zijn van culturele, historische en politieke verschillen. België en Nederland worden trouwens vaak in verschillende modellen ingedeeld. In België, maar ook binnen de EU, spreekt men omwille van de globalisering, het deficit in de openbare financiën, de vergrijzing en de blijvend hoge werkloosheid bovendien steeds meer van de nood aan een 'actieve welvaartsstaat'. De idee is dat men door een actief arbeidsmarktbeleid meer mensen aan het werk helpt en houdt om de financiën van de sociale zekerheid in evenwicht te brengen en om sociale uitsluiting te vermijden. ${ }^{9}$ Voor welk model men ook wenst te opteren en hoe men het kind ook wil dopen, vast staat dat elke welvaartsstaat een sociale en economische 'minimumbescherming biedt aan alle burgers die dit nodig

G. Esping-Andersen, The Three Worlds of Welfare Capitalism, Princeton University Press I99o, I.

4 Instituut voor Sociaal Recht, KUL, 'De Actieve Welvaarsstaat', <www.law.kuleuven.be/isr/ onderzoek/onlinerapportenbijlagen/actieve\%2owelvaartstaat.PDF >, I.

5 H. Deleeck, De Architectuur van de welvaartsstaat opnieuw bekeken, Leuven, Acco, 2008, 27.

6 'In het sociaal-democratische model (Denemarken, Zweden, Noorwegen, deels Nederland) staan individualisme en universalisme centraal. Iedere burger geniet individuele rechten. Het model is er op gericht marktafhankelijkheid en ongelijkheid te reduceren door staatsinterventie.' Zie H. Dillen, Naar een ontspannen arbeidsmarkt: over een nieuwe evenwicht tussen arbeid en zorg, $<$ www.ethesis.net>; H. Deleeck, De Architectuur van de welvaarsstaat opnieuw bekeken, Leuven, Acco, 2008, 78-80.

7 'De conservatief-corporatistische welvaartsstaat (Europees continent: o.a. Frankrijk, Duitsland en België) is gebaseerd op het kostwinnersmodel en benadrukt het belang van familiariteit. Dit model wordt verder gekenmerkt door een ontwikkeld sociale zekerheidssysteem per beroepscategorie, aansluitend bij de arbeidsmarktpositie.' H. Dillen, Naar een ontspannen arbeidsmarkt: over een nieuwe evenwicht tussen arbeid en zorg, www.ethesis.net; H. Deleeck, De Architectuur van de welvaartsstaat opnieuw bekeken, Leuven, Acco, 2008, 78-80.

8 'De liberale welvaartsstaat (VK, VS, Australië en Canada) vertrouwt op de werking van de markt. Er is slechts een minimum aan sociale voorzieningen ontwikkeld en de overheid grijpt enkel in wanneer de markt tekort schiet. Privé-verzekeringsstelsels spelen een grote rol en de meeste sociale voorzieningen komen tot stand in samenwerking met werkgevers.' H. Dillen, Naar een ontspannen arbeidsmarkt: over een nieuwe evenwicht tussen arbeid en zorg, <www.ethesis.net>; H. Deleeck, De Architectuur van de welvaartsstaat opnieuw bekeken, Leuven, Acco, 2008, 78-80.

9 H. Deleeck, De Architectuur van de welvaartsstaat opnieuw bekeken, Leuven, Acco, 2008, I04; Instituut voor Sociaal Recht, KUL, 'De Actieve Welvaartsstaat', <www.law.kuleuven.be/isr/onderzoek/ onlinerapportenbijlagen/actieve\%2owelvaartstaat.PDF $>$, 3-4. 
hebben'. ${ }^{\text {Io }}$ Het is net de bedoeling van deze bijdrage om te begrijpen wat die bescherming is volgens het nationale en internationale recht (II) en hoe die bescherming juridisch afgedwongen kan worden (III), (IV) en (V).

\section{Rechtswaarborgen}

3. De welvaartsstaat biedt een (sociale en economische) bescherming aan alle burgers die het nodig hebben. De welvaart van de burger beschermen is, naast het beschermen tegen criminaliteit, een van de wezenlijke taken van een moderne staat. ${ }^{\text {II }}$ Wat men dient te verstaan onder sociale en economische bescherming is vastgelegd in de internationale mensenrechtenverdragen en de nationale grondwetten (I). Het is daarbij evenwel ook van wezenlijk belang om te begrijpen dat deze inhoudelijke vereisten van de welvaartsstaat slechts kunnen bloeien als ook procedurele voorwaarden vervuld zijn (II). Respect voor de rechtsstaat en democratie zijn onontbeerlijk om de minimumbescherming vorm te geven door middel van wetten en goed bestuur. Daarbij is een goed begrip van de verhouding tussen wetgever en rechter ook cruciaal.

\section{Materieel: zowel klassieke als sociale en economische mensenrechten}

\section{a. Verschillende bronnen}

4. Pas in de laatste drie decennia heeft België de meeste sociale en economische grondrechten in juridisch bindende verdragen en de Grondwet verankerd. Dit wil evenwel niet zeggen dat daarvoor absoluut geen bescherming bestond voor deze rechten. Sommige sociale en economische grondrechten werden immers reeds erkend in de Universele Verklaring voor de Rechten van de Mens van I948, ${ }^{12}$ en ook de klassieke burgerlijke en politieke mensenrechtenverdragen, zoals het Europees Verdrag voor de Rechten van de Mens (EVRM) dat reeds in I955 door België werd geratificeerd, ${ }^{13}$ garanderen rechtstreeks ${ }^{14}$ of onrechtstreeks via het

Io Dit is een van de essentiële functies van de sociale zekerheid volgens Van Langendonck. Hij omschrijft de twee functies van de sociale zekerheid als volgt: 'Zij moet een minimumbescherming bieden aan alle burgers die dit nodig hebben, en zij moet een verzekering organiseren voor arbeidsinkomen, voor degenen die van hun arbeid moeten leven.' J. Van Langendonck, Een andere kijk op sociale zekerheid, Antwerpen, Intersentia, 2009, 27.

II Instituut voor Sociaal Recht, KUL, 'De Actieve Welvaartsstaat', <www.law.kuleuven.be/isr/ onderzoek/onlinerapportenbijlagen/actieve\%2owelvaartstaat.PDF $>, \&$.

I2 Zie artikel 22 (recht op maatschappelijke zekerheid), artikel 23 (recht op arbeid en op bescherming tegen werkloosheid), artikel 24 (recht op rust en op eigen vrije tijd), artikel 25 (recht op een levensstandaard, die hoog genoeg is voor de gezondheid en het welzijn van zichzelf).

I3 Het EVRM werd op I4 juni I955 geratificeerd. Het Internationaal Verdrag inzake burgerrechten en politieke rechten (IVBPR) werd door België geratificeerd op 2I april ig83.

I4 Zie bijvoorbeeld artikel II EVRM (vrijheid van vergadering en vereniging, met inbegrip van het recht om vakverenigingen op te richten en zich bij vakverenigingen aan te sluiten voor de bescherming van zijn belangen) of artikel I Protocol nr. I bij het EVRM (het recht op eigendom). 
gelijkheidsbeginsel en antidiscriminatieverbod ${ }^{15}$ bepaalde rechten die een sociale of economische component hebben. En ook op nationaal vlak kon men soms terugvallen op de Grondwet ${ }^{16}$ of de wetten die sociale rechten toekenden. Men was in de praktijk echter lange tijd vooral op de klassieke burgerlijke en politieke rechten aangewezen om de welvaartsstaat te beschermen. Het Europees Sociaal Handvest $(\mathrm{ESH})$ en het Internationaal Verdrag inzake Economische Sociale en Culturele Rechten (IVESCR) waren in België lang juridisch irrelevant. Pas begin jaren tachtig van de vorige eeuw kwam de kentering: het IVESCR werd door België in I983 geratificeerd ${ }^{17}$ en het ESH werd in I990 aanvaard. ${ }^{18}$ Met de ineenstorting van het communisme werden de sociale en economische grondrechten door België en andere westerse landen gemakkelijker erkend en beschermd. ${ }^{19}$ Uiteindelijke werd deze erkenning op 3I januari 1994 ook verankerd in de Belgische Grondwet door middel van artikel 24bis (dat bij de coördinatie van de Grondwet op I7 februari 1994 artikel 23 geworden is)..$^{20}$ Ook artikel 7 bis in verband met duurzame ontwikkeling, dat in de Grondwet ingevoegd werd in 2007, ${ }^{21}$ dient vermeld te worden, al moet benadrukt worden dat het Grondwettelijk Hof er niet aan vermag te toetsen, in tegenstelling tot artikel 23 van de Grondwet. ${ }^{22}$ Ook het Handvest van de Grondrechten van de Europese Unie $\left(2000^{23}\right)$, dat een volledige titel aan solidariteit wijdt, benadrukt de groeiende erkenning van sociale en economische grondrechten. ${ }^{24}$ Een onderzoek

I5 Artikel I4 EVRM is beperkt tot de rechten vermeld in het EVRM. Protocol nr. I2 bij het EVRM bevat daarentegen een algemeen discriminatieverbod. België heeft dat Protocol evenwel nog niet geratificeerd (het heeft het wel ondertekend op 4 november 2000).

I6 Zie het (huidige) artikel 24 van de Grondwet in verband met de vrijheid van onderwijs en het recht op onderwijs.

I7 België ondertekende het IVESCR op ro december I968, en ratificeerde het op 2I april I983.

I8 Het Europees Sociaal Handvest werd door België geratificeerd op I6 oktober I990. Het herziene Europese Sociaal Handvest werd geratificeerd op 2 maart 2004. Het Protocol met betrekking tot het collectieve klachtrecht werd geratificeerd op 23 juni 2003.

I9 R. Delarue merkt evenwel op dat de groeiende steun voor een universele en daadwerkelijke toepassing van de IAO-verdragen in de jaren 1995 en verder vooral gesitueerd moet worden in de context van de toenemende globalisering van de economie. België ratificeerde het eerste fundamentele arbeidsverdrag in 1944 en het laatste in 2002 ( $<w w w . i l o . o r g / d y n /$ normlex/en/f?p=Iooo :I00II:0::NO:IOoII:PIOOII_DISPLAY_BY,PIOOII_CONVENTION_TYPE_CODE:I,F $>$ ). R. Delarue, 'Sociaaleconomische grondrechten en het perspectief van de IAO', in: $\mathbf{W}$. Rauws en M. Stroobant (ed.), Sociale en economische grondrechten, Antwerpen/Louvain-la-Neuve, Intersentia/Anthemis, I98.

20 B.S. I2 februari i994. Zie infra nr. 5 voor integrale weergave van dat artikel.

2I Artikel 7 bis van de Grondwet: 'Bij de uitoefening van hun respectieve bevoegdheden streven de federale Staat, de gemeenschappen en de gewesten de doelstellingen na van een duurzame ontwikkeling in haar sociale, economische en milieugebonden aspecten, rekening houdend met de solidariteit tussen de generaties.'

22 Zie artikel I42 van de Grondwet en artikel I Bijzondere Wet Grondwettelijk Hof.

23 Zie artikel 6.I. van het Verdrag betreffende de Europese Unie: 'De Unie erkent de rechten, vrijheden en beginselen die zijn vastgesteld in het Handvest van de grondrechten van de Europese Unie van 7 december 2000, als aangepast op I 2 december 2007 te Straatsburg, dat dezelfde juridische waarde als de Verdragen heeft.'

24 In titel IV zitten artikel 27 (het recht op informatie en raadpleging van de werknemers binnen de onderneming), artikel 28 (het recht op collectieve onderhandelingen en op collectieve actie), artikel 29 (het recht op toegang tot arbeidsbemiddeling), artikel 30 (bescherming bij kennelijk onredelijk ontslag), artikel 3I (rechtvaardige en billijke arbeidsomstandigheden en -voorwaarden), artikel 32 (het verbod van kinderarbeid en de bescherming van jongeren op het werk), artikel 33 (het beroeps- en gezinsleven), artikel 34 (sociale zekerheid en sociale bijstand), 
naar de rechtswaarborgen in een herijkte welvaartsstaat zal dus rekening moeten houden met al die verschillende bronnen. Het volstaat daarbij niet om enkel te verwijzen naar één welbepaald grondwetsartikel of verdrag, of zelfs een welbepaalde categorie van grondwetsartikelen of verdragen.

\section{b. Verschillende rechten ter bescherming van de menselijke waardigheid}

5. Het is binnen het kader van dit artikel een onmogelijke opdracht om alle relevante (sociale en economische) mensenrechten op te sommen en exhaustief te analyseren. Dit is ook niet nodig. Het centrale uitgangspunt van al deze rechten lijkt immers steeds hetzelfde: ieder moet een menswaardig leven kunnen leiden. ${ }^{25}$ Dit is de ratio legis van alle (sociale en economische) grondrechten en vormt dan ook de ultieme toetssteen waaraan een herijking van de welvaartsstaat dient te voldoen.

\section{Artikel 23 van de Belgische Grondwet illustreert deze benadering treffend:}

'Ieder heeft het recht een menswaardig leven te leiden.

Daartoe waarborgen de wet, het decreet of de in artikel 134 bedoelde regel, rekening houdend met de overeenkomstige plichten, de economische, sociale en culturele rechten, waarvan ze de voorwaarden voor de uitoefening bepalen.

Die rechten omvatten inzonderheid:

$1^{\circ}$ het recht op arbeid en op de vrije keuze van beroepsarbeid in het raam van een algemeen werkgelegenheidsbeleid dat onder meer gericht is op het waarborgen van een zo hoog en stabiel mogelijk werkgelegenheidspeil, het recht op billijke arbeidsvoorwaarden en een billijke beloning, alsmede het recht op informatie, overleg en collectief onderhandelen;

$2^{\circ}$ het recht op sociale zekerheid, bescherming van de gezondheid en sociale, geneeskundige en juri-

dische bijstand;

$3^{\circ}$ het recht op een behoorlijke huisvesting;

$4^{\circ}$ het recht op de bescherming van een gezond leefmilieu;

$5^{\circ}$ het recht op culturele en maatschappelijke ontplooiing.'

De opsomming van de economische en sociale rechten door de Belgische grondwetgever is bewust niet-limitatief. Het is aan de wetgever om de gepaste sociale en economische rechten te waarborgen zodat ieder het recht heeft om een menswaardig leven te leiden. In dit artikel zullen we vooral verder aandacht besteden aan de

artikel 35 (de gezondheidszorg), artikel 36 (de toegang tot diensten van algemeen economische belang), artikel 37 (milieubescherming) en artikel 38 (consumentenbescherming). Daarnaast kan ook verwezen worden naar artikel I (de menselijke waardigheid), artikel I5 (de vrijheid van beroep en het recht te werken), artikel 23 (gelijkheid van vrouwen en mannen), artikel 24 (de rechten van het kind), artikel 25 (de rechten van ouderen), artikel 26 (integratie van personen met een handicap).

25 Zie artikel 23 van de Grondwet en artikel I van het Handvest van de grondrechten van de EU. Het ESH verwijst dan weer niet naar de menselijke waardigheid. 
volgende in artikel 23 van de Grondwet vermelde rechten: het recht op sociale zekerheid, bescherming van de gezondheid en sociale, geneeskundige en juridische bijstand en het recht op huisvesting. ${ }^{26}$ We zullen evenwel ook stilstaan bij rechtspraak over het recht op arbeid, cruciaal voor een goed begrip van de actieve welvaartsstaat, en het recht op de bescherming van een gezond leefmilieu als daar belangrijke gevolgtrekkingen uit kunnen worden afgeleid voor een goed begrip van de sociale of economische grondrechten.

6. Op het internationale vlak heeft België de meeste sociale en economische grondrechten erkend en lijkt het zelfs een voortrekkersrol te willen nemen. Voor een bekrachtiging van het herziene Europees Sociaal Handvest is het bijvoorbeeld niet nodig alle artikelen te onderschrijven. ${ }^{27}$ De meeste lidstaten maken daar veelvuldig gebruik van, ${ }^{28}$ terwijl België slechts een beperkt aantal artikelen niet aanvaard heeft. ${ }^{29}$ Zo heeft België enkel de artikelen I9, SI2 (het recht voor de migrerende werknemer op onderwijs in zijn eigen moedertaal), 26, \$2 (recht op waardigheid bij de arbeidstaak), ${ }^{30} 23$ (recht van ouderen op sociale bescherming), 24 (recht op bescherming in geval van beëindiging van de dienstbetrekking), 27 (recht van werknemers met gezinsverantwoordelijkheid op gelijke kansen en een gelijke behandeling), 28 (het recht van werknemersvertegenwoordigers op bescherming in de onderneming en op verlening van passende voorzieningen) en $3 \mathrm{I}$ (het recht op huisvesting) van het herziene sociale handvest niet aanvaard. ${ }^{3 \mathrm{I}}$ Het is daarbij opvallend dat het recht op huisvesting niet gewaarborgd wordt, terwijl het recht op een behoorlijke huisvesting expliciet vermeld wordt in artikel 23 van de Grondwet. ${ }^{32}$ De vrees bestond blijkbaar dat de internationale standaard hoger zou komen te liggen dan de nationale. ${ }^{33}$

26 Het recht op huisvesting speelt zoals het Grondwettelijk Hof opmerkt 'een centrale rol in de welvaart en het economisch beleid van de moderne samenleving'. Grondwettelijk Hof, arrest nr. 93/2008 van 26 juni 2008.

27 Het IVESCR kent geen gelijkaardig systeem, al zijn voorbehouden of interpretatieve verklaringen mogelijk. België heeft dat verdrag aanvaard met een verklaring over de toepassing van artikel 2 van dat verdrag.

28 Uitzonderingen zijn Frankrijk, Italië en Portugal, die alle artikelen hebben aanvaard. Nederland heeft alle artikelen behalve één aanvaard (artikel I2).

29 Zie <www.coe.int/t/dghl/monitoring/socialcharter/Presentation/ProvisionTableRev_en.pdf $>$.

30 Artikel 26, SI heeft uitsluitend betrekking op seksuele intimidatie en is wel door België aanvaard. De tweede paragraaf bestrijkt de andere vormen van verbaal geweld of moedwillige intimidatie die de waardigheid van een werknemer aantasten.

$3 \mathrm{I}<\mathrm{http}: / /$ conventions.coe.int/Treaty/Commun/ListeDeclarations.asp? $\mathrm{NT}=\mathrm{I} 63 \& \mathrm{CM}=8 \& \mathrm{DF}=\& \mathrm{CL}=$ ENG\&VL $=\mathrm{I}>$.

32 Doordat artikel I6 en 30 ESH wel erkend zijn, zal het recht op huisvesting van bepaalde kwetsbare categorieën wel beschermd zijn. Zie ESH-Comité, International Federation of Human Rights Leagues (FIDH) t. België, nr. 62/20I0 van 2I maart 2010 (ivm de huisvesting van Roma zigeuners). <www.coe.int/t/dghl/monitoring/socialcharter/Complaints/Complaints_en.asp>.

33 Memorie van toelichting bij het wetsontwerp houdende instemming met het herziene Europese Sociale Handvest en met de bijlage, gedaan te Straatsburg op 3 mei 1996, Parl. St. Senaat, 2-838/I. Voor artikel 3I: 'Het is niet zeker of de huidige wetgeving in België - ondanks initiatieven op het vlak van woonzekerheid - voldoende het recht op huisvesting waarborgt zoals dit in dit artikel wordt omschreven. De ratificatie ervan lijkt in de huidige stand van zaken dan ook niet aangewezen maar kan in een later stadium misschien wel worden doorgevoerd.' 
Ook voor de meeste andere geciteerde artikelen bestond de vrees dat de Belgische wetgeving in strijd was met deze bepalingen. ${ }^{34}$

\section{c. Traditionele verschillen}

7. Traditioneel wordt benadrukt dat sociale en economische grondrechten een ander soort rechten zijn dan burgerlijke en politieke rechten. Sociale en economische mensenrechten zouden geen juridisch afdwingbare rechten, geen subjectieve rechten bevatten, maar slechts rechten die gerealiseerd moeten worden via beleidsmaatregelen. Ze zouden geen onmiddellijke verplichting bevatten voor de Staat, maar enkel een verplichting tot geleidelijke verwezenlijking van de geformuleerde doelstelling. Terwijl burgerlijke en politieke rechten initieel beschouwd werden als afweerrechten, i.e. de staat dient zich te onthouden van enige inmenging, argumenteerde men dat sociale en economische rechten een prestatieplicht voor de staat inhouden. Sociale grondrechten worden voorgesteld als programmarechten, ze zouden onvoldoende helder en precies zijn geformuleerd om er als burger rechtstreekse aanspraken tegen de overheid uit te kunnen putten. ${ }^{35}$ Het individu kan zich slechts op een sociaal grondrecht beroepen voor zover deze in de wetgeving nader is uitgewerkt.

8. Ook in de Belgische context vindt men dit traditioneel onderscheid. Zo wordt in de parlementaire voorbereiding van artikel 23 van de Grondwet herhaaldelijk verklaard dat artikel 23 van de Grondwet geen directe werking heeft (zie ook infra). ${ }^{6}$ De

34 Memorie van toelichting bij het wetsontwerp houdende instemming met het herziene Europese Sociale Handvest en met de bijlage, gedaan te Straatsburg op 3 mei 1996, Parl. St. Senaat, 2-838/r.Voor artikel I9, \$2: 'Dit geldt echter niet voor het artikel I9, \$ I2, over het recht voor de migrerende werknemer op onderwijs in zijn eigen moedertaal. De daadwerkelijke toepassing van dit recht kan door de Gemeenschappen in ons land niet worden gewaarborgd.' Voor artikel 23: 'Paragraaf a van dit artikel voorziet dat ouderen over voldoende middelen moeten beschikken om hen in staat te stellen een fatsoenlijk bestaan te leiden en actief deel te nemen aan het openbare, maatschappelijke en culturele leven. Onder meer om budgettaire redenen kunnen voorzieningen die erop gericht zijn voor "voldoende middelen" te zorgen, zoals het gewaarborgd minimum voor bejaarden (wet van I april I969), echter niet tot buitenlandse niet EU onderdanen worden uitgebreid.' Voor artikel 24: 'De belangrijkste hinderpaal was de motiveringsplicht voor de beëindiging van de tewerkstelling. In het Belgische recht wordt het ontslag in regel immers niet gemotiveerd tenzij voor welbepaalde categorieën beschermde werknemers zoals zwangere vrouwen. Aangezien dit nieuwe artikel eveneens vertrekt van de motiveringsplicht, stelt de regering voor het niet te bekrachtigen.' Voor artikel 26, \$2: 'Daarentegen is de verwoording van de tweede paragraaf onduidelijk en kan bij de naleving ervan problemen stellen.' Voor artikel 27: 'Een van de voornaamste moeilijkheden is opnieuw de motiveringsplicht van het ontslag waarvan in paragraaf 3 in dit artikel eveneens wordt uitgegaan. Ook is het twijfelachtig of de opvangmogelijkheden voor kinderen in België voldoende zijn uitgebouwd om te beantwoorden aan de criteria van de eerste paragraaf. In de huidige stand van zaken lijkt het wenselijk om het hele artikel niet te bekrachtigen.' Over artikel 28: 'Het nieuwe artikel sluit nauw aan bij het IAO-verdrag nr. I35 inzake de bescherming van werknemersvertegenwoordigers in de onderneming en de hen te verlenen faciliteiten. Dit IAO-verdrag kon niet worden aanvaard aangezien de bepalingen inzake bescherming en toe te kennen faciliteiten verder reiken dan de Belgische wetgeving ter zake. Om dezelfde reden stelt de regering voor dit artikel 28 niet te bekrachtigen.'

35 G. Maes, 'Twintig jaar sociale grondrechten in de grondwet', in: W. Rauws en M. Stroobant (ed.), Sociale en economische grondrechten, Antwerpen/Louvain-la-Neuve, Intersentia/Anthemis, I48.

36 G. Maes, 'Twintig jaar sociale grondrechten in de grondwet', in: W. Rauws en M. Stroobant (ed.), Sociale en economische grondrechten, Antwerpen/Louvain-la-Neuve, Intersentia/Anthemis, I48. 
inroepbaarheid van de sociale en economische rechten die opgesomd zijn in artikel 23 van de Grondwet wordt bovendien op het eerste gezicht expliciet beperkt door de tekst zelf van artikel 23, tweede lid, van de Grondwet. Overeenkomstig die bepaling komt het immers de federale wetgever en de gemeenschap- en gewestwetgevers toe om, ieder binnen zijn bevoegdheid, dit recht te waarborgen en de voorwaarden voor de uitoefening ervan te bepalen, rekening houdend met de overeenkomstige plichten. De wetgever heeft een Grondwettelijke plicht om de opgesomde sociale rechten, als elementen van het recht op een menswaardig leven te waarborgen, ${ }^{37}$ maar het komt hem toe om de concrete maatschappelijke keuzes te maken die een bijzondere impact hebben op het concrete leven van veel personen. De keuzes moeten aldus principieel gemaakt worden door de regelgever en het bestuur, onder de marginale toetsing van de hoven en rechtbanken, de Raad van State en het Grondwettelijk Hof..$^{8}$ Hetzelfde geldt voor de meeste grondrechten die in het IVESCR of het herziene ESH zijn vastgelegd: ook daar argumenteert de rechtspraak en de doctrine traditioneel dat de bepalingen van deze verdragen geen directe werking hebben en slechts programmatorische rechten zijn.

\section{d. Vervaging van de verschillen}

9. Kort na de val van de Berlijnse muur verkondigde de Verklaring van Wenen (I993) de onderlinge afhankelijkheid van burgerlijke en politieke rechten enerzijds en sociale en economische rechten anderzijds. Deze verklaring is een belangrijke evolutie, die toelaat om de dichotomie tussen beide soorten rechten in vraag te stellen. Het is in elk geval opvallend dat de rechtspraak van het EHRM expliciet aanvaard heeft dat ook burgerlijke en politieke rechten positieve verplichtingen met zich meebrengen voor de overheid. Bovendien heeft het EHRM ook vele sociale kwesties (betreffende bijvoorbeeld pensioenen, sociale zekerheid, werkloosheid, sociale bijstand en sociale huisvesting) via de omweg van het EVRM behandeld (zie infra nr. 4I). ${ }^{39}$ Anderzijds blijkt duidelijk uit de 'rechtspraak' van het VN-Comité bij het IVESCR en het Europees Comité voor Sociale Rechten (ESH-Comité) dat sociale en economische rechten ook negatieve verplichtingen meebrengen voor de overheid. Het ESHComité laat bovendien niet na om naar de rechtspraak van het EVRM te verwijzen..$^{\circ}$ De vraag weerklinkt dus steeds luider of de verschillen tussen beide rechten niet aan het vervagen zijn.

Zie artikel 23, eerste lid van de Grondwet.

38 G. Maes, 'Twintig jaar sociale grondrechten in de grondwet', in: W. Rauws en M. Stroobant (ed.), Sociale en economische grondrechten, Antwerpen/Louvain-la-Neuve, Intersentia/Anthemis, I46.

39 F.M.C. Vlemminx, 'Het inlezen van economische, sociale en culturele rechten in het EVRM door het EHRM', NJCM-Bulletin: 60 jaar EVRM, 2010, 813-826.

40 A.C. Hendriks, 'De invloed van de EHRM-jurisprudentie op het ESH-Comité', NJCM-Bulletin: 6o jaar EVRM, 2010, 754-765. 


\section{Procedureel}

Io. De rechtswaarborgen voor de welvaartsstaat kunnen evenwel niet louter materieel van aard zijn. De inhoudelijke vereisten van de welvaartsstaat kunnen slechts bloeien als ook procedurele voorwaarden vervuld zijn. Respect voor de rechtsstaat en democratie zijn onontbeerlijk om de bescherming vorm te geven door middel van wetten en goed bestuur en af te dwingen via onafhankelijke en onpartijdige rechters. De uitwerking van de sociale rechten wordt zowel door de Belgische Grondwet als door de internationale verdragen grotendeels aan de appreciatiebevoegdheid van de nationale wetgever overgelaten. Dit is evenwel geen vrijbrief voor willekeur. De nationale of internationale rechterlijke controle is marginaal, maar moet wel degelijk mogelijk zijn en uitgevoerd worden. Eigenlijk kan verwezen worden naar de sinds 1949 geformuleerde doelstelling van de Raad van Europa om de 'democratie, rechtsstaat en mensenrechten' te bevorderen. Sociale en economische mensenrechten, en dus ook de welvaartstaat, floreren enkel optimaal in een rechtsstaat en een democratie.

II. De verwijzing naar de rechtsstaat betekent dat iedereen, dus ook de supranationale overheden die bepaalde nieuwe sociale of economische maatregelen opleggen, gebonden zijn door de wet en in het bijzonder de grondwettelijk en verdragsrechtelijk vastgelegde sociale en economische mensenrechten, zoals toegepast door de rechter. ${ }^{4 \mathrm{I}}$ De verwijzing naar de democratie verduidelijkt dan weer dat er nood is aan inspraak van het volk bij de uitwerking van de sociale rechten. In België zou men in die context niet alleen kunnen verwijzen naar de parlementaire democratie, maar ook naar het sociale overlegmodel dat gehanteerd wordt. De vraag rijst dan ook of een supranationale overheid zoals de Europese Unie dezelfde democratische garanties biedt voor de uitwerking van de sociale rechten. Indien niet, dan rijst de vraag of men bij een overdracht van bevoegdheden aan supranationale instellingen ${ }^{42}$ een beroep kan doen op het standstill-beginsel om te argumenteren dat de uitwerking van de sociale rechten minder democratisch dreigt te verlopen dan voorheen. Het is voorlopig onduidelijk of in België een herijking van de welvaartsstaat getoetst kan worden aan de beginselen van de rechtstaat of de democratie. Bij het sluiten van internationale verdragen die vereisen dat de begrotingssituatie van de algemene overheid in evenwicht is of een overschot heeft, en waarbij staten er zich toe verbinden om via een nationaal correctiemechanisme automatisch maatregelen uit te voeren om de afwijkingen binnen een welbepaalde termijn te corrigeren ${ }^{43} \mathrm{zal}$ alvast nauwlettend onderzocht moeten worden of de wetgever zich bewust is van de

4I Voor een goed begrip van de term 'rechtsstaat' zie E. Jurgens, 'Het verschil tussen Rechtsstaat en Rule of Law', NJCM-Bulletin 20II, 867-872.

42 Via bijvoorbeeld artikel 34 van de Grondwet.

43 Zie het Verdrag inzake stabiliteit, coördinatie en bestuur in de Economische en Monetaire Unie tussen het Koninkrijk België, de Republiek Bulgarije, het Koninkrijk Denemarken, de Bondsrepubliek Duitsland, de Republiek Estland, Ierland, de Helleense Republiek, het Koninkrijk Spanje, de Franse Republiek, de Italiaanse Republiek, de Republiek Cyprus, de Republiek Letland, de Republiek Litouwen, het Groothertogdom Luxemburg, Hongarije, Malta, het Koninkrijk der Nederlanden, de Republiek Oostenrijk, de Republiek Polen, de Portugese Republiek, Roemenië, de Republiek Slovenië, de Slowaakse Republiek, de Republiek Finland en het Konink- 
draagwijdte van de nieuwe internationale verplichtingen en de impact ervan op de welvaartsstaat.

\section{Preventieve juridische controle op naleving sociale en economische grondrechten}

I2. Sociale en economische grondrechten worden traditioneel niet beschouwd als subjectieve rechten, maar zelfs als men deze visie aanhangt zijn ze juridisch relevant, niet in het minst bij de totstandkoming van nieuwe regelgeving. In België spreekt de Raad van State, afdeling wetgeving zich in adviezen aan de federale en regionale regelgever preventief en op abstracte wijze uit over alle mogelijke grondwettigheidsbezwaren en onverenigbaarheden met internationale verdragen. ${ }^{4}$ Hoewel deze adviezen niet bindend zijn, wordt meestal een groot juridisch gezag aan deze adviezen verleend. De Raad van State buigt zich, in tegenstelling tot de Nederlandse Raad van State, niet over de opportuniteit van de wetgeving, maar maakt een strikt juridische analyse, een objectieve toets. Hij staat de wetgever bij om onder meer te vermijden dat ongrondwettigheden na de goedkeuring aan het licht zouden komen of de internationale aansprakelijkheid in het gedrang komt. Een dergelijke juridische controle laat toe om na te gaan welke grenzen volgens het hoogste Belgische administratieve rechtscollege aan de wetgever worden opgelegd door sociale en economische rechten. Vaak zal de Raad van State, afdeling wetgeving, zich baseren op bestaande rechtspraak van supranationale hoven en het Grondwettelijk Hof, die we in het volgende deel zullen behandelen. Doordat de Raad van State, afdeling wetgeving, evenwel niet gebonden is door de middelen die de partijen aanvoeren, kunnen bepaalde aspecten in principe meer of anders belicht worden dan in een traditioneel contentieux.

I3. De grenzen die de Raad van State, afdeling wetgeving, aangeeft voor het optreden van de wetgever zijn net als bij de rechtspraak van de Raad van State, afdeling bestuursrechtspraak, of het Grondwettelijk Hof (welke verder onderzocht wordt, infra, IV) in eerste instantie het legaliteitsbeginsel en het zogenoemde standstillbeginsel. Het legaliteitsbeginsel is vooral een democratische garantie die voortvloeit uit artikel 23 van de Grondwet: bepaalde essentiële zaken moeten omwille van hun maatschappelijke belang door de formele wetgever, en niet door de regering, worden vastgelegd. Het standstill-beginsel is meer inhoudelijk van aard en vloeit voort uit zowel de Grondwet als de internationale verdragen. De wetgever kan het bereikte sociale beschermingsniveau in principe niet terugschroeven.

rijk Zweden, gedaan te Brussel op 2I maart 20I2. De Raad van State, afdeling wetgeving, buigt zich momenteel over de instemmingswet en instemmingsdecreten.

44 Op Europees niveau bestaat geen gelijkaardig mechanisme. Voor een overzicht van de bestaande niet-rechterlijke mechanismen zie J. Morijn en P. van Sasse van Usselt, 'Niet-rechterlijke handhaving van het EU-Grondrechtenhandvest: een analyse van de eerste stappen', NJCM-Bulletin, 2012, 295-3II. 


\section{Legaliteitsbeginsel}

I4. De wijze waarop artikel 23 van de Grondwet is geformuleerd, vertoont zoals opgemerkt in de rechtsleer grote gelijkenissen met andere grondwetsbepalingen waarin een zogenoemd (aan de formele wetgever) voorbehouden aangelegenheid wordt omschreven (fiscaliteit, onderwijs, strafrecht...), of anders gezegd, bepalingen waarin een 'versterkt' legaliteitsbeginsel zit vervat. ${ }^{45}$ B. Steen merkt op dat de Raad van State, afdeling wetgeving, na enige aarzeling geoordeeld heeft dat de materies die in artikel 23 van de Grondwet zijn opgesomd wel degelijk als een voorbehouden aangelegenheid dienen te worden beschouwd. ${ }^{46}$ Hoewel de Raad van State in een advies van 2005 nog heeft geoordeeld dat de aangelegenheden in artikel 23 van de Grondwet, in casu het recht op sociale zekerheid, niet aan de wetgever waren voorbehouden, ${ }^{47}$ erkende het reeds in $200 \mathrm{I}$ dat 'de wetgever de Koning hoe dan ook geen onbeperkte bevoegdheden kan verlenen op het stuk van de economische en sociale rechten, aangezien de wetgever zelf krachtens de Grondwet de taak heeft die rechten te waarborgen' en besloot hij dat '[d]e wet (...) dus op zijn minst de basisprincipes [moet] bepalen of bepaalde grenzen [moet] vaststellen waarbinnen de Koning in deze aangelegenheid mag optreden'. ${ }^{8}$ Talloze wetgevende initiatieven onder meer inzake sociale zekerheid, ${ }^{49}$ sociaal statuut der zelfstandigen, ${ }^{50}$ sociale

45 B. Steen, 'Artikel 23 van de Grondwet en de rechtspraak van de Raad van State', in: W. Rauws en M. Stroobant (ed.), Sociale en economische grondrechten, Antwerpen/Louvain-la-Neuve, Intersentia/ Anthemis, I32.

46 B. Steen, 'Artikel 23 van de Grondwet en de rechtspraak van de Raad van State', in: W. Rauws en M. Stroobant (ed.), Sociale en economische grondrechten, Antwerpen/Louvain-la-Neuve, Intersentia/ Anthemis, I32.

47 Rvs, afdeling wetgeving, advies 3829I/I, 5 april 2005 over een voorontwerp van wet tot invoering van een structureel aanpassingsmechanisme aan de welvaart van plafonds en inkomstendrempels alsook van sociale uitkeringen, Parl. St. Kamer, nr. 5IKI948/I, I2.

48 Rvs, afdeling wetgeving, advies 3I834/4 van I9 juni 200I, over een voorontwerp van wet betreffende Belgacom, Parl. St. Senaat 2000-or, nr. 825/I, 9-Io. B. Steen verwijst ook nog naar twee latere adviezen Rvs, afdeling wetgeving, advies nr. $43646 / 2$ van 24 oktober 2007 over een voorontwerp van decreet 'modifiant le décret du I3 mars 2003 relatif à l'agrément des agences de placement', Parl. St. W. Parl. 2008-09, nr. 95I/I, I08; Rvs, afdeling wetgeving, advies 4435I/I/2/3/4 van $2 \mathrm{I}$ april 2008 over een voorontwerp van wet 'houdende diverse bepalingen (I)', Parl. St. Kamer 2007-08, nr. I200/I, 267.

49 Rvs, afdeling wetgeving, advies 39420 van 22 en 23 november 2005 over een voorontwerp van wet betreffende het Generatiepact, Parl. St. Kamer 2005-06, nr. 2128/I.

50 Rvs, afdeling wetgeving, advies 39563/I van 20 december 2005 over een ontwerp van koninklijk besluit 'tot uitvoering van een stelsel van uitkeringen voor moederschapshulp ten gunste van vrouwelijke zelfstandigen en tot wijziging van het koninklijk besluit van 12 december $200 \mathrm{I}$ betreffende de dienstencheques', onuitg.; Rvs, afdeling wetgeving, advies 4I4I3 van I3 oktober 200 I over een ontwerp van koninklijk besluit 'tot invoering van een adoptieverlof en een adoptieuitkering ten gunste van de zelfstandige', ontuig. 
huisvesting, ${ }^{51}$ de zorgverzekering,,$^{52}$ arbeidsbemiddeling ${ }^{53}$ en sociale bijstand ${ }^{54}$ werden intussen getoetst aan het legaliteitsbeginsel van artikel 23 van de Grondwet en vaak werd een schending vastgesteld door de Raad van State, afdeling wetgeving. 55 Over de toepassing van het legaliteitsbeginsel heerst evenwel nog steeds enige onzekerheid. B. Steen argumenteerde in 2010 dat uit artikel 23 van de Grondwet een versterkt legaliteitsbeginsel voortvloeit, dat in concreto evenwel soepel moet worden toegepast, terwijl M. Bossuyt in datzelfde jaar eerder de mening was toegedaan dat er sprake is van een 'afgezwakt' legaliteitsbeginsel..$^{56}$ Uit de recente adviespraktijk blijkt alvast dat de Raad van State niet aarzelt om de gevestigde praktijk in vraag te stellen in het licht van het legaliteitsbeginsel 'dat sommige aangelegenheden voorbehoudt aan een wetgever'. Advies 50623 van de algemene vergadering van de Raad van State over een decreet houdende Vlaamse sociale bescherming ${ }^{57}$ en advies 51476 in verband met de werkloosheidsreglementering zijn daarvan een treffend voorbeeld. Aangezien deze adviezen de huidige toepassing van het legaliteitsbeginsel door de Raad van State duidelijk verwoorden, lijkt het gepast om te besluiten met een uitvoerig citaat: ${ }^{8}$

5I Zie Rvs, afdeling wetgeving, advies $39536 / \mathrm{VR} / 3$ van 24 januari 2006 over een voorontwerp van decreet 'houdende wijziging van het decreet van 15 juli 1997 houdende de Vlaamse Wooncode', Parl.St. Vl. Parl. 2005-06, nr. 824/I.

52 Rvs, afdeling wetgeving, advies $44583 / 3$ van II juni 2008 over een voorontwerp van decreet tot wijziging van het decreet van 30 maart 1999 houdende de organisatie van de zorgverzekering, Parl. St. Vl. Parl. 2007-08, nr. I8Io/I.

53 Rvs, afdeling wetgeving, advies 46577/I van I9 mei 2009 over een ontwerp van besluit van de Vlaamse Regering houdende de organisatie van de arbeidsbemiddeling en de beroepsopleiding', onuitg.

54 Rvs, afdeling wetgeving, advies 50623/AV/3 van 24 januari 2012 over een decreet 'houdende de Vlaamse sociale bescherming', Parl. St. Vl. Parl. 20II-20I2, nr. I603/I.

55 Zie bijvoorbeeld Rvs, advies $47567 / \mathrm{I} / 2 / 3 / 4$ van 5 en 6 januari 2010 over een voorontwerp van wet 'houdende diverse bepalingen', Parl. St. Kamer 2009-2010, nr. 2423/I (over de inhaalpremie voor langdurig zieken): Steunend op deze rechtspraak is de afdeling Wetgeving onder meer van oordeel dat wetsbepalingen waarbij de Koning gemachtigd wordt om, inzake gezondheid, de aard en het bedrag van een prestatie te bepalen, de begunstigden van een prestatie aan te wijzen en de toekenningsvoorwaarden ervan te definiëren artikel 23 van de Grondwet schenden.' Zie ook advies 4659I/I van 7 mei 2009 over een voorontwerp van wet 'houdende diverse bepalingen over tewerkstelling in tijden van crisis', Parl. St. Kamer 2008-2009, nr. 2003/I; Rvs, afdeling wetgeving, advies $47258 / \mathrm{I}$ van 5 oktober 2009 over een ontwerp van amendement ' $\mathrm{nr}$. I bij een ontwerp van wet houdende sociale bepalingen', Parl. St. Kamer 2009-2010, nr. 2299; Rvs, afdeling wetgeving, advies 475396/2 van 22 december 2009 over een ontwerp van koninklijk besluit 'houdende toekenning van een uitkering ten voordele van de zelfstandige die tijdelijk zijn activiteit stopzet om palliatieve zorgen te geven aan [het] kind of zijn partner', onuitg., Rvs, afdeling wetgeving, advies 50623/AV/3 van 24 januari 2012 over een decreet 'houdende de Vlaamse sociale bescherming', Parl. St. Vl. Parl. 20II-2012, nr. I603/r.

56 B. Steen, 'Artikel 23 van de Grondwet en de rechtspraak van de Raad van State', in: W. Rauws en M. Stroobant (ed.), Sociale en economische grondrechten, Antwerpen/Louvain-la-Neuve, Intersentia/ Anthemis, I32; M. Bossuyt, 'Artikel 23 van de Grondwet in de rechtspraak van het Grondwettelijk Hof', in: W. Rauws en M. Stroobant (ed.), Sociale en economische grondrechten, Antwerpen/ Louvain-la-Neuve, Intersentia/Anthemis, I34.

57 Rvs, afdeling wetgeving, advies 50623/AV/3 van 17 en 24 januari 20I2, over een voorontwerp van decreet 'houdende de Vlaamse sociale bescherming', Parl. St. Vl. Parl. 20II-20I2, nr. I603/I.

58 Rvs, advies 5I467/I van 2I juni 2012 over een ontwerp van koninklijk besluit 'tot wijziging van het koninklijk besluit van 25 november I99I houdende de werkloosheidsreglementering in het kader van de versterkte degressiviteit van de werkloosheidsuitkeringen en tot wijziging van het koninklijk besluit van 28 december 201 I tot wijziging van de artikelen 27,36 , 36ter, 36quater, 
'Uit de rechtspraak van het Grondwettelijk Hof blijkt (...) ook dat uit het gegeven dat artikel 23, tweede lid, van de Grondwet bepaalt dat de bevoegde wetgever "de voorwaarden voor de uitoefening [bepaalt]" van de erin gewaarborgde rechten, niet kan worden afgeleid dat de bevoegde wetgever de uitvoerende macht niet zou mogen belasten met "de nadere uitwerking" van de door hem georganiseerde of gewaarborgde (sociaal-economische grond)rechten ${ }^{59}$ of van de vooraf door de wetgever zelf gemaakte "keuzes" ${ }^{60}$ of vastgestelde "beginselen", ${ }_{11}$ "grenzen" $6_{2}$ of "essentiële elementen". ${ }_{3}$ Bij de beoordeling of een machtiging aan de regering in aangelegenheden waarop artikel 23 van de Grondwet van toepassing is, niet te ver gaat, houdt het Grondwettelijk Hof in het bijzonder rekening met de aard van de geregelde aangelegenheid, zoals bijvoorbeeld het gegeven dat een omvattende regeling van de aangelegenheid door de wetgever "de doeltreffendheid van het door hem vastgestelde beleid in het gedrang zou brengen, ${ }^{6}$ het gegeven dat de betrokken "maatregelen gemakkelijk (...) [kunnen] worden aangepast om tegemoet te komen aan de vereisten van de technische ontwikkeling", ${ }^{5}$ het gegeven dat een algemene en abstracte bepaling onverenigbaar is met de keuze van de wetgever om een geboden hulp te laten variëren in functie van de behoeften van de betrokken gerechtigden ${ }^{66}$, het gegeven dat de regeling op "relatief soepele wijze [moet] kunnen worden aangepast aan de evolutie van de noden en middelen" ${ }^{67}$ in het betrokken beleidsdomein of de "bijzonder technische en ingewikkelde" ${ }^{16}$ aard van de regeling. In recentere arresten oordeelde het Hof zelfs dat een delegatie aanvaardbaar is voor zover de machtigingen betrekking hebben op "de tenuitvoerlegging" of op "het aannemen"70 van maatregelen "waarvan het onderwerp door de bevoegde wetgever is aangegeven". Uit deze arresten blijkt desalniettemin dat de wetgever zich er bij het bepalen van het "onderwerp" van een te waarborgen sociaal, economisch of cultureel grondrecht niet toe kan beperken het zonder meer aan de regering over te laten om de draagwijdte, de toekenningsvoorwaarden en het personele toepassingsgebied van deze rechten te bepalen.

27. Het ontwerp bevat verschillende machtigingen aan de Vlaamse Regering. Het komt de Raad van State voor dat voor zover deze machtigingen het zonder meer aan de regering overlaten om

36 sexies, 40, 59quinquies, 59sexies, 63, 79, 92, 93, 94, 97, I24 en I3Isepties van het koninklijk besluit van 25 november I99I houdende de werkloosheidsreglementering', onuitg. (de voetnoten in het citaat zijn de voetnoten van het advies zonder de verwijzing naar de gelijkluidende voetnoten in advies $50623 / \mathrm{AV} / 3$ ).

59 Grondwettelijk Hof, nr. 43/2006, I5 maart 2006, B.2I (m.b.t. het recht op maatschappelijke dienstverlening); Grondwettelijk Hof, nr. 64/2008, I7 april 2008, B.32.I (m.b.t. het recht op sociale zekerheid).

6o Grondwettelijk Hof, nr. I47/2005, 28 september 2005, B.II.6.

6I Grondwettelijk Hof, nr. 37/98, I april I998, B.4.4; Grondwettelijk Hof, nr. I03/2006, 2I juni 2006, B.3.3.

62 Grondwettelijk Hof, nr. I8/98, I8 februari ı998, B.6.

63 Grondwettelijk Hof, nr. I89/2005, I4 december 2005, B.Io.3; Grondwettelijk Hof, nr. 66/2007, 26 april 2007, B.I0.7.

64 Grondwettelijk Hof, nr. I89/2005, I4 december 2005, B.Io.3.

65 Grondwettelijk Hof, nr. I89/2005, I4 december 2005, B.Io.3.

66 Grondwettelijk Hof, nr. 43/2006, I5 maart 2006, B.2I.

67 Grondwettelijk Hof, nr. 103/2006, 2I juni 2006, B.3.6.

68 Grondwettelijk Hof, nr. 64/2008, I7 april 2008, B.32.2.

69 Grondwettelijk Hof, nr. Ior/2008, ro juli 2008, B.39; Grondwettelijk Hof, nr. I82/2008, I8 december 2008, B.6.3. Zie ook Grondwettelijk Hof, nr. 73/2009, 5 mei 2009, B.6.4.

70 Grondwettelijk Hof, nr. I35/2010, 9 december 2010, B.I5 (in casu betrof het een systeem van programmering van de bedden in de rustoorden en de rust- en verzorgingstehuizen); Grondwettelijk Hof, nr. I5I/2010, 22 december 20I0, B.4 (in casu werd het aan de regering overgelaten de grenswaarden voor emissie en immissie van geluidshinder, de methodes en de meetapparatuur te bepalen). 
wezenlijke elementen te bepalen inzake de draagwijdte van de te waarborgen sociale rechten, ${ }^{71}$ de voorwaarden voor hun toekenning ${ }^{72}$ en het personele toepassingsgebied van de ontworpen regeling, 73 het ontworpen decreet op gespannen voet staat met het in artikel 23 , tweede lid, van de Grondwet opgenomen legaliteitsbeginsel.74

28. Het komt aan de decreetgever toe in het decreet zelfeen aantal regels op te nemen die de draagwijdte, de toekenningsvoorwaarden en het toepassingsgebied nader bepalen, of minstens bepalingen op te nemen - biju. voorzien in criteria of procedures, minima of maxima bepalen, enz. - aan de hand waarvan deze regels door de regering verder kunnen worden ingevuld.'

De toekomst zal moeten uitwijzen of de Raad van State hiermee strenger is dan (de meest recente rechtspraak van) het Grondwettelijk Hof, die zoals de Raad zelf aangeeft, lijkt aan te nemen dat aan het legaliteitsbeginsel voldaan is als 'het onderwerp door de bevoegde wetgever is aangegeven' ${ }^{75}$ Het is alvast niet onredelijk om te eisen dat het parlement de essentiële keuzes moet maken in aangelegenheden die cruciaal zijn voor de menselijke waardigheid van eenieder. In het licht hiervan kan men aanvoeren dat het Grondwettelijk Hof de lat te laag legt.

7I Zo laat bijv. artikel 43, § 3, van het ontwerp het zonder meer aan de Vlaamse Regering over de hoogte van het bedrag van de 'premie voor jonge kinderen' te bepalen en laat artikel 46 van het ontwerp het zonder meer aan de Vlaamse Regering over de 'grensbedragen voor de toepassing van de maximumfactuur' te betalen.

72 Zo laat bijv. artikel $44,2^{\circ}$, van het ontwerp het zonder meer aan de Vlaamse Regering over om de toekenningsvoorwaarde inzake preventieve gezinsondersteuning te bepalen (zie ook voor het belang van een nadere regeling daarvan, supra nr. I8) en laat artikel 32 S , van het ontwerp het zonder meer aan de Vlaamse Regering over om de leeftijd te bepalen vanaf wanneer jaarlijks de bijdrage moet worden bepaald.

73 Zo maakt bijv. artikel 30, § 2, van het ontwerp het mogelijk dat de Vlaamse Regering het aantal gerechtigden in het tweetalige gebied Brussel-Hoofdstad beperkt door de termijn te bepalen waarbinnen de inwoners van dat gebied zodra dat mogelijk is bij de zorgkas dienen aan te sluiten, zonder dat het ontwerp aangeeft op grond waarvan die termijnbepaling dient te gebeuren.

74 Een gelijkaardige opmerking werd al gemaakt in advies 44.583/3 van II juni 2008 over een ontwerp dat heeft geleid tot het decreet van ig december 2008 tot wijziging van het decreet van 30 maart 1999 houdende de organisatie van de zorgverzekering, Parl. St. Vl. Parl., 2007-2008, nr. I8Io/I), en in advies $39.536 / V R / 3$ van 24 januari 2006 over een ontwerp dat heeft geleid tot het decreet van 15 december 2006 houdende wijziging van het decreet van I5 juli 1997 houdende de Vlaamse Wooncode, Parl. St. Vl. Parl., 2005-2006, nr. 824/I.

75 De Raad beseft dit en besluit advies 51476 met de volgende bewoordingen: 'Hoewel de lering van advies 50.623/AV/3 ook kan worden betrokken op genoemd artikel 7 , § I, derde lid, i, van de besluitwet van 28 december 1944 , en wellicht nog op andere onderdelen van dat lid, zal het uiteindelijk aan het Grondwettelijk Hof toekomen om uitsluitsel te geven over de overeenstemming van genoemde wetsbepaling met artikel 23, tweede lid, van de Grondwet.' Voor een advies waar de Raad van State de mildere toets lijkt over te nemen, en aanneemt dat het volstaat dat 'de wetgever het onderwerp van de aldus gedelegeerde maatregel heeft aangegeven' zie Rvs, afdeling wetgeving, advies nr. 48963/2 van I5 december 2010 over een ontwerp van koninklijk besluit 'ter uitvoering van artikel 9I, \$3, van de basiswet van I2 januari 2005 betreffende het gevangeniswezen en de rechtspositie van de gedetineerden', onuitg. 


\section{Standstill}

15. De afdeling wetgeving heeft er reeds in 1996 op gewezen dat uit artikel 23 van de Grondwet ook een standstill-effect voortvloeit. ${ }^{6}$ Hiermee heeft de Raad van State, afdeling wetgeving, relatief snel na de aanname van dit artikel aangegeven dat aan artikel 23 van de Grondwet ook een inhoudelijke toets moest worden verbonden. In essentie betekende dit volgens de Raad van State, afdeling wetgeving, dat een aanzienlijke verlaging van het beschermingsniveau van de in artikel 23 van de Grondwet vernoemde rechten concreet en redelijk moest worden gemotiveerd en ingegeven moest zijn door een dwingende reden van algemeen belang. ${ }^{77}$ In 2006 sluit de Raad van State, afdeling wetgeving, zich in Verenigde Kamers aan bij de formulering van het Grondwettelijk Hof: artikel 23 van de Grondwet staat eraan in de weg dat het bestaande (sociale) beschermingsniveau aanzienlijk zou worden verlaagd zonder dat daarvoor redenen met betrekking tot het algemeen belang bestaan en de wetgever mag zelf oordelen hoe hij het recht op de meest adequate wijze waarborgt. ${ }^{8}$

I6. Initieel hadden de meeste adviezen waarin getoetst werd aan het standstill-beginsel betrekking op het recht op de bescherming van een gezond leefmilieu.79 Sinds enkele jaren wordt het beginsel evenwel steeds meer toegepast met betrekking tot andere sociale rechten, zoals het recht op billijke arbeidsvoorwaarden, ${ }^{80}$ het recht

76 Rvs, advies 25046/9 van 22 april 1996 over amendementen bij een ontwerp van decreet 'relatif aux déchets', Parl. St. W. Parl., nr. 49.

77 B. Steen, 'Artikel 23 van de Grondwet en de rechtspraak van de Raad van State', in: W. Rauws en M. Stroobant (ed.), Sociale en economische grondrechten, Antwerpen/Louvain-la-Neuve, Intersentia/ Anthemis, 123 en de aldaar geciteerde adviezen.

78 Rvs, afdeling wetgeving, advies $39563 / \mathrm{VR} / 3$, van 24 januari 2006 over een voorontwerp van decreet 'houdende wijziging van het decreet van 15 juli 1997 houdende de Vlaamse Wooncode', Parl. St. Vl. Parl. 2005-06, nr. 824/I (in casu was er sowieso geen schending van de stand-still want er was geen aanzienlijke achteruitgang van het beschermingsniveau).

79 B. Steen, 'Artikel 23 van de Grondwet en de rechtspraak van de Raad van State', in: W. Rauws en M. Stroobant (ed.), Sociale en economische grondrechten, Antwerpen/Louvain-la-Neuve, Intersentia/ Anthemis, I2I.

80 Rvs, afdeling wetgeving, advies 34373/I van I2 december 2002 over een ontwerp van koninklijk besluit 'houdende sommige maatregelen inzake organisatie van de arbeidstijd in de ondernemingen voor radio- en televisieuitzendingen', onuitg: 'Artikel 23 van de Grondwet garandeert onder meer het recht op billijke arbeidsvoorwaarden. Deze bepaling verzet er zich tegen dat normen worden aangenomen waarbij de graad van bescherming van de rechten, die erdoor worden erkend, aanzienlijk zou worden verminderd ten opzichte van het beschermingsniveau in de wetgeving die van toepassing was op de dag dat ze in werking is getreden. De in artikel 2 van het ontwerp opgenomen afwijking is, zeker in het licht van artikel 23 van de Grondwet, verregaand. De maximumgrens van elf uur arbeid per dag mag worden overschreden, maar er wordt geen nieuwe maximumgrens gesteld en door artikel $\mathrm{I}$ wordt de minimumperiode van dagelijkse rust opgeheven, zodat theoretisch zelfs vierentwintig uur arbeid per dag mogelijk wordt. Weliswaar bevatten andere bepalingen zekere temperingen (artikel 2, in fine: er moeten gelijkwaardige periodes van inhaalrust worden toegekend in de drie volgende maanden; artikel 4: de maximale wekelijkse arbeidsduur bedraagt vierentachtig uur ), maar toch rijst de vraag of de regeling, door haar algemeenheid, kan worden geacht in overeenstemming te zijn met de uit artikel 23 van de Grondwet voortvloeiende relatieve standstill-verplichting. Aldus lijkt de ontworpen regeling niet de nodige garanties te bevatten dat de graad van bescherming niet aanzienlijk zal worden verminderd ten opzichte van het beschermingsniveau dat het personeel van de betrokken sector genoot op de dag dat artikel 23 van de Grondwet in werking is getreden.' 
op een behoorlijke huisvesting ${ }^{81}$ en het recht op maatschappelijke bijstand. ${ }^{82}$ De Raad van State lijkt bovendien aan te nemen dat de verplichting tot standstill van toepassing is op alle economische, sociale en culturele rechten die in artikel 23 van de Grondwet worden gehuldigd. ${ }^{8}{ }_{3}$ In een advies over het voorstel tot invoering van de zogenoemde zonsondergangclausule (ook wel gekend als sunset law), waardoor het toepassen van elke wet van rechtswege wordt opgeschort of opgeheven als gevolg van het louter verstrijken van een of andere termijn, werd gewezen op het problematisch karakter van deze regeling: 'Een dispositief dat voorschrijft dat de toepassing van een wet wordt opgeschort of dat ze wordt opgeheven, louter als gevolg van het feit dat een bepaalde termijn is verstreken, zonder dat de wetgever concreet heeft kunnen vaststellen dat het opschorten van de toepassing of de opheffing van de desbetreffende wet gerechtvaardigd wordt door motieven die verband houden met het algemeen belang, is op zich strijdig met die verplichting, althans in de gevallen waarin zulks een aanzienlijke vermindering van de reeds bestaande graad van bescherming [van sociale, economische of culturele grondrechten] tot gevolg heeft. ${ }^{18}$ Dit is een opvallend advies omdat de Raad van State meestal, zoals bij de recente grote pensioenhervormingen, ${ }^{85}$ geen schending vaststelt van de verplichting tot standstill of minstens heel omzichtig te werk gaat bij de toetsing aan deze verplichting. ${ }^{86}$ Zo leest men vaak dat 'gelet op de complexiteit van de (...) ont-

8I Rvs, afdeling wetgeving, advies 39575 van Io januari 2006 over een voorontwerp van decreet 'portant modification du Code wallon du logement', Parl. St. W. Parl. 2005-2006, nr. 322. Zie ook Rvs, afdeling wetgeving, advies $39563 / \mathrm{VR} / 3$, van 24 januari 2006 over een voorontwerp van decreet 'houdende wijziging van het decreet van 5 juli 1997 houdende de Vlaamse Wooncode', Parl. St. Vl. Parl. 2005-06, nr. 824/I en Rvs, afdeling wetgeving, advies 50764/4 van I6 januari 2012 over een ontwerp van besluit van de Waalse regering 'modifiant l'arrêté du Gouvernement wallon du 6 september 2007 organisant la location des logement géré par la Société wallonne du Logement ou par les sociétés de logement de service public', onuitg.; Rvs, afdeling wetgeving, advies 49253/4 van 2 maart 2oII over een ontwerp van besluit van het Collège de la Commission communautaire française 'modifiant l'arrêté du Collège de la Commisssion communautaire française du 2 avril 2009 portant application du décret du 22 mars 2007 relatif à la politique d'hébergement et d'accueil à mener envers les personnes âgées', onuitg.

82 Rvs, advies 4995I/4 van II juli 2oII over een wetsvoorstel 'tot wijziging van de wetgeving met het oog op het bezweren van de asielcrisis', Parl. St. Kamer 20I0-20II, nr. 8I3/I.

83 Zie advies $46040 / 2$ van 22 april 2009 over een wetsvoorstel 'tot invoering van de zonsondergangsclausule', Parl. St. Kamer 2008-2009, nr. 1758 .

84 Zie advies $46040 / 2$ van 22 april 2009 over een wetsvoorstel 'tot invoering van de zonsondergangsclausule', Parl. St. Kamer 2008-2009, nr. 1758 met verwijzing naar I. Hachez, Le principe de stanstill dans le droit des droits fondamentaux: une irréversibilité relative, Bruylant, Salkkoulas en Nomos Verlagsgesellschaft, 2008, nr. 602.

85 Hoewel het beginsel zelfs niet vermeld wordt in het advies bij de programmawet, kan men uit dit stilzwijgen meer dan waarschijnlijk afleiden dat dit gewoon betekent dat de Raad van State, afdeling wetgeving, van oordeel was dat het beginsel in casu niet geschonden was. Rvs, advies $50742 / \mathrm{I} / 2$ van 20 december 201 I over de amendementen nrs. 2 tot 50 en amendementen nrs. I en volgende bij het wetsontwerp 'houdende diverse bepalingen', Parl.St. Kamer 20II-I2, nr. I952/003 en 004.

86 Uitzonderingen zijn Rvs, advies 34373/I van I2 december 2002 over een ontwerp van koninklijk besluit 'houdende sommige maatregelen inzake organisatie van de arbeidstijd in de ondernemingen voor radio- en televisieuitzendingen', onuitg.; Rvs, advies 4995I/4 over een wetsvoorstel 'tot wijziging van de wetgeving met het oog op het bezweren van de asielcrisis', Parl. St. Kamer 20I0-20II, nr. 8I3/I en, zij het minder expliciet, Rvs, afdeling wetgeving, advies 49253/4 van 2 maart 20 II over een ontwerp van besluit van het Collège de la Commission communautaire française 'modifiant l'arrêté du Collège de la Commisssion communautaire française du 2 avril 
worpen maatregelen (...) het uitermate moeilijk is om de ontworpen maatregel te beoordelen in het licht van artikel 23 van de Grondwet en het eruit voortvloeiende standstill-beginsel ${ }^{187}$ of wordt geopperd dat de Raad van State, afdeling wetgeving, niet kan nagaan of het standstill-beginsel, dat in artikel 23 van de Grondwet vervat ligt, gerespecteerd is omdat de ontworpen regeling op essentiële punten onduidelijk is en vol lacunes zit. ${ }^{8}$ Soms worden de ontwerpers uitgenodigd om nog eens zelf na te gaan of er geen sprake is van een aanzienlijke verlaging van bescherming en of er een rechtvaardiging is voor de achteruitgang die is ingegeven door het algemeen belang. ${ }^{89}$

I7. Kenmerkend voor de heersende houding van de Raad van State ten aanzien van sociale en economische grondrechten lijkt advies 49323/I. Op basis van de rechtspraak van het Grondwettelijk Hof oordeelt de Raad dat de vervaging van het onderscheid tussen arbeiders en bedienden maar slechts geleidelijk aan kan plaatsvinden en dat mede gelet op deze rechtspraak 'het niet uitgesloten is dat de (negatieve) gevolgen van een bepaalde maatregel voor de graad van sociaal- en arbeidsrechterlijke bescherming worden gecompenseerd door de (positieve) gevolgen van andere maatregelen op dat vlak. ${ }^{90}$ De Raad besluit dan ook dat het uitermate moeilijk is om de punctuele maatregelen die betrekking hebben op de ontslagregeling voor arbeiders en bedienden en de schorsing van de uitvoering van de arbeidsovereenkomst en van gedeeltelijke arbeid voor bedienden te beoordelen in het licht van het standstill-beginsel. De Raad argumenteert eigenlijk dat een volledig overzicht van de volledige hervorming vereist is. Deze voorzichtige benadering is opvallend als men het contrasteert met de opmerking in hetzelfde advies over het gelijkheidsbeginsel waarbij de Raad van State expliciet stelt dat de wetgever in de memorie van toelichting een verantwoording dient op te nemen, 'waarbij bijvoorbeeld wordt aangegeven in welk ruimer kader de thans ontworpen maatregelen desgevallend moeten worden gesitueerd en op welke wijze de wetgever door deze en latere maatregelen geleidelijk beoogt te komen tot een volledige harmonisering van het arbeids- en

2009 portant application du décret du 22 mars 2007 relatif à la politique d'hébergement et d'accueil à mener envers les personnes âgées', onuitg.

87 Rvs, afdeling wetgeving, advies 49253/4 van 2 maart 201 I over een voorontwerp van wet 'houdende aanpassing van de wet van I februari 201 i houdende verlenging van de crisisimaatregelen en uitvoering van het interprofessioneel akkoord, en tot uitvoering van het compromis van de Regering met betrekking tot het ontwerp van interprofessioneel akkoord.'

88 Rvs, afdeling wetgeving, advies 39575 van Io januari 2006 over een voorontwerp van decreet 'portant modification du Code wallon du logement'. Zie ook advies 4995I/4 van II juli 201 I over een wetsvoorstel 'tot wijziging van de wetgeving met het oog op het bezweren van de asielcrisis', Parl. St. Kamer 20I0-20II, nr. 8I3/I', punt 4.4.

89 Rvs, afdeling wetgeving, advies 49253/4 van 2 maart 2orI over een ontwerp van besluit van het Collège de la Commission communautaire française 'modifiant l'arrêté du Collège de la Commisssion communautaire française du 2 avril 2009 portant application du décret du 22 mars 2007 relatif à la politique d'hébergement et d'accueil à mener envers les personnes âgées', onuitg. in verband met de beperking van het vereiste minimumaantal vierkante meters voor de gemeenschappelijke ruimtes in de ouderenzorg.

90 Rvs, afdeling wetgeving, advies $49323 / \mathrm{I}$ van 3 maart $201 \mathrm{I}$ over een voorontwerp van wet 'houdende aanpassing van de wet van I februari 201 i houdende verlenging van de crisisimaatregelen en uitvoering van het interprofessioneel akkoord, en tot uitvoering van het compromis van de Regering met betrekking tot het ontwerp van interprofessioneel akkoord', Parl. St. Kamer 20Io2011, nr. 1322. 
sociaalrechtelijk statuut van de onderscheiden categorieën van werknemers, waarbij eventuele verschillen in behandeling niet langer zijn gebaseerd op het criterium van de aard van het werk dat door het Grondwettelijk Hof als niet objectief en redelijk te verantwoorden is bestempeld.' ${ }^{91}$ Deze opmerking had ook perfect onder artikel 23 van de Grondwet kunnen worden gemaakt: zoals hiervoor vermeld, wordt de geleidelijke verwezenlijking van de geformuleerde doelstelling vaak zelfs als een wezenlijk kenmerk van sociale en economische rechten beschouwd. ${ }^{22}$ Dit advies illustreert eigenlijk perfect twee zaken. Ten eerste toont het aan dat de Raad van State nog steeds gemakkelijker een schending van klassieke grondrechten, zoals het gelijkheidsbeginsel, dan van sociale en economische grondrechten vaststelt. ${ }^{93}$ Men is nog wat onwennig omtrent de precieze draagwijdte van deze laatste categorie grondrechten en verkiest - indien mogelijk - terug te vallen op bijvoorbeeld het gelijkheidsbeginsel om zijn punt te maken. Ten tweede toont dit advies de beperking van het standstill-beginsel goed aan: de Raad van State, afdeling wetgeving, gaat niet na of de arbeiders en bedienden elk afzonderlijk als categorie voldoende beschermd zijn op arbeids- en sociaalrechterlijk vlak, wat eigenlijk de meest relevante vraag lijkt, maar controleert enkel of hun globaal beschermingsniveau niet verminderd wordt zonder reden van algemeen belang. Het gelijkheidsbeginsel, hoewel in principe neutraal van aard, ${ }^{94}$ zal er op termijn waarschijnlijk toe leiden dat de bescherming van de minst beschermde categorie (de arbeiders) meer afgestemd zal worden op de andere categorie (de bedienden). Het gelijkheidsbeginsel realiseert dus in feite waar artikel 23 van de Grondwet voorlopig niet in slaagt en waar de tegenstanders van sociale en economische grondrechten voor vrezen: de arbeids- en sociaalrechterlijke bescherming van arbeiders via gerechtelijke weg bepalen (en in casu verhogen).

\section{Rechtstreekse bescherming en de plichten van het individu}

I8. De vraag rijst waarom en of de Raad van State, afdeling wetgeving, de toetsing van artikel 23 van de Grondwet beperkt tot het legaliteitsbeginsel en het standstillbeginsel. Zoals het hiervoor aangehaalde advies 49323/I perfect illustreert, is de toetsing aan artikel 23 hierdoor beperkt. Er lijken evenwel op het eerste gezicht geen

9I Rvs, afdeling wetgeving, advies 49323/I van 3 maart 20 II over een voorontwerp van wet 'houdende aanpassing van de wet van I februari $201 \mathrm{I}$ houdende verlenging van de crisismaatregelen en uitvoering van het interprofessioneel akkoord, en tot uitvoering van het compromis van de Regering met betrekking tot het ontwerp van interprofessioneel akkoord', Parl. St. Kamer 20Io2011 , nr. I322.

92 In hetzelfde advies merkt de Raad ook op dat 'erover gewaakt dient te worden dat ook de afwijkende opzeggingstermijnen in overeenstemming zijn met artikel 4, 4 van het Europees Sociaal Handvest.' Daarmee toetst de Raad ook rechtstreeks aan het ESH zonder een beroep te doen op de standstill.

93 De voorkeur om terug te vallen op het gelijkheidsbeginsel valt waarschijnlijk ook te verklaren door de wil van de Raad van State, afdeling wetgeving, om na te gaan of de nieuwe regeling tegemoetkomt aan de vaststelling van het Grondwettelijk Hof dat er een schending is van het gelijkheidsbeginsel.

94 Theoretisch kan de bescherming zowel naar boven als naar beneden toe gerealiseerd worden. In de praktijk lijkt de tweede optie weinig waarschijnlijk. 
redenen te zijn om de objectieve toets in het kader van een preventieve juridische controle te beperken. Waarschijnlijk is de voorzichtige houding ingegeven door de overtuiging dat artikel 23 van de Grondwet geen subjectieve rechten toekent. Deze vaststelling betekent mijn inziens evenwel niet dat de sociale en economische rechten geen juridische bescherming (kunnen) bieden, maar eerder dat het individu deze bescherming niet kan opeisen voor de rechter in het subjectief contentieux omdat de wetgever dat niet heeft gewild of omdat de norm te vaag is (zie ook infra nr. 23). Dat is een fundamenteel verschil. Bij een objectieve toets, zoals in het geval van de preventieve adviesaanvraag voor de Raad van State, zal de rechter zich enkel de vraag moeten stellen of de wet in overeenstemming is met de hogere norm. ${ }^{55} \mathrm{De}$ Raad van State moet dus ook controleren of de wet of het besluit de economische sociale en culturele rechten waarborgt zoals de Grondwet en de internationale verdragen dat vereisen.

I9. De adviespraktijk toont aan dat de Raad van State, afdeling wetgeving, soms ook effectief inhoudelijk toetst aan artikel 23 van de Grondwet zonder een beroep te (moeten) doen op de standstill. In een zaak die betrekking had op een Vlaams decreet dat vereist dat de persoon die in aanmerking wenst te komen voor sociale huisvesting zich bereid moet tonen om Nederlands te leren, oordeelde de Raad dat het moest onderzoeken 'wat de draagwijdte is van de grondwettelijke regel dat het recht op een behoorlijke huisvesting door de decreetgever wordt gewaarborgd "rekening houdend met de overeenkomstige plichten". ${ }^{96} \mathrm{Na}$ de vaststelling dat die taalverplichting effectief kan bijdragen tot het totstandkomen van een betere communicatie tussen verhuurders en huurders van sociale huurwoningen stelt de Raad dat het een proportionaliteitstoets moet doorvoeren om na te gaan of de minimumbescherming van het recht op een behoorlijke huisvesting gewaarborgd blijft: 'Evenwel is vereist dat de verplichting voor geen enkele categorie van personen de essentie van het recht op een behoorlijke huisvesting of van andere grondrechten aantast, niet verder reikt dan noodzakelijk om de beoogde doelstelling als hoger omschreven te bereiken en voor de betrokkenen of voor bepaalde categorieën onder hen geen onevenredig zware gevolgen heeft.' De Raad van State stelt in navolging hiervan onder meer dat er voldoende onderwijsaanbod beschikbaar moet zijn, dat dit kosteloos of ten hoogste tegen een zeer bescheiden bijdrage beschikbaar dient te zijn en dat de sanctie evenredig moet zijn. Het is daarbij opvallend dat de Raad van State, afdeling wetgeving, in een volgend punt onderzoekt of de standstill-verplichting gerespecteerd is, hiermee aangevend dat er twee verschillende toetsen dienen gemaakt te worden. ${ }^{97}$ Dit valt wellicht te verklaren door de wil om enerzijds de

95 In dezelfde zin: X, Grondwet en EVRM, Brugge, die Keure 20II, 79: 'Uit de geciteerde rechtspraak van de Raad van State blijkt dat deze soms - ten onrechte - meent, dat voor de toepassing van artikel $23 \mathrm{GW}$. in een objectief contentieux er uit het grondwetsartikel subjectieve rechten moeten worden kunnen afgeleid.'

96 Rvs, afdeling wetgeving, advies $39536 / \mathrm{VR} / 3$ van 24 januari 2006 over een voorontwerp van decreet 'houdende wijziging van het decreet van I5 juli 1997 houdende de Vlaamse Wooncode', Parl.St. Vl. Parl. 2005-06, nr. 824/I.

97 Rvs, afdeling wetgeving, advies $39536 / \mathrm{VR} / 3$ van 24 januari 2006 over een voorontwerp van decreet 'houdende wijziging van het decreet van I5 juli ig97 houdende de Vlaamse Wooncode', 
negatieve verplichtingen te beoordelen (is de maatregel gerechtvaardigd) en anderzijds de positieve plichten van de overheid te onderzoeken. Zoals we verder zullen zien, heeft de Raad van State, afdeling bestuursrechtspraak, in het arrest Coomans immers aangenomen dat de standstill een bijzondere, afgezwakte vorm is om positieve verplichtingen vast te stellen (infra $\mathrm{n}^{\circ} 27$ ).

Een ander advies dat betrekking had op sociale huisvesting baseerde zich op arrest IOI/2008 van het Grondwettelijk Hof (zie infra nr. 3I \& 32) om een schending van artikel 23 van de Grondwet vast te stellen zonder verwijzing naar de standstill. Doordat het decreet inhield dat een feitelijke situatie, namelijk het feit dat iemand het huis niet meer als hoofdverblijfplaats betrekt, binnen een maand de ontbinding van rechtswege van de huurovereenkomst met zich kon meebrengen, waren er onvoldoende waarborgen voor elke huurder dat zijn recht op een behoorlijke huisvesting niet zou worden geschonden..$^{8}$ De Raad besloot dan ook dat de ontwerpers voldoende waarborgen voor elke huurder dienden te voorzien en bovendien de ontworpen regeling moesten verantwoorden in het licht van de doelstelling die het ontwerp nastreefde.

Deze benadering, die focust op de vraag of de vereiste bescherming van het recht op huisvesting is gewaarborgd, beperkt zich niet tot dat recht. Zo heeft de Raad van State, afdeling wetgeving, artikel 4.4 van het ESH met betrekking tot het recht van alle werknemers op een redelijke opzeggingstermijn bij beëindiging van hun dienstbetrekking rechtstreeks toegepast, met verwijzing naar de conclusies van het ESH-Comité van Io december 20I0. Daarbij werd vastgesteld dat de opzegtermijn van 56 dagen voor arbeiders die tien jaar gewerkt hebben te kort was volgens het ESH-Comité. ${ }^{99}$ In adviezen die verwezen naar het recht op geneeskundige verzorging stelt de Raad van State, afdeling wetgeving, dan weer vast dat aan dit recht de verplichting voor de overheid beantwoordt om de passende maatregelen te nemen, rekening houdend met de gezondheidsbehoeften en de beschikbare middelen, om aan eenieder een billijke toegang tot de gezondheidszorg te verzekeren. Opnieuw wordt niet verwezen naar de standstill, maar naar een proportionaliteitstoets die rekening houdt met de beschikbare middelen en de gezondheidsbehoeften om eenieder een minimumbescherming, in casu een billijke toegang tot de gezondheidszorg, te verzekeren. ${ }^{100}$ Zonder hier dieper op in te gaan besluit de Raad van State, afdeling wetgeving, dat het voorzien in een selectie van de in aanmerking komende

Parl.St. Vl. Parl. 2005-06, nr. 824/I, punt 5.4. (terwijl de proportionaliteitstoets behandeld wordt van punt 5.2.2 tot 5.3.6).

98 Rvs, advies $45479 / 3$ van 9 december 2008 over een ontwerp van besluit van de Vlaamse Regering 'tot wijziging van de reglementering betreffende het sociaal huurstelsel en de overdracht van onroerende goederen', onuitg.

99 Rvs, afdeling bestuursrechtspraak, advies 50257/I tot 50264/I van 29 september 20II met betrekking tot verschillende koninklijke besluiten waaronder het koninklijk besluit 'tot vaststelling van opzeggingstermijnen voor de ondernemingen die onder het Paritair Comité voor het kappersbedrijf en de schoonheidszorg ressorteren', onuitg. Zie ook de latere adviezen 50657/I tot $50663 / \mathrm{I}$ en 50667/I en 50668/I van I3 december 20II.

Ioo Rvs, advies 25197 van 4 maart 1997 over een ontwerp van koninklijk besluit 'betreffende de centra voor het wegnemen en transplanteren van organen van menselijke oorsprong'; Rvs, advies

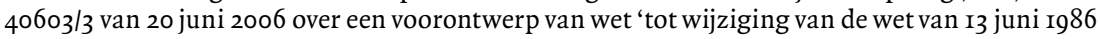
betreffende het transplanteren van organen', Parl. St. Kamer 2005-2006, nr. 2680/I. 
ontvangers van nieren op een wachtlijst op zich niet in strijd is met het recht op geneeskundige verzorging.

20. De vraag of de vereiste sociale bescherming is gewaarborgd, houdt in essentie een evenredigheidstoets in die sommige rechters kan afschrikken. Bovendien lijkt deze benadering op het eerste gezicht minder vrijheid te geven aan de wetgever dan het standstill-beginsel. Beide beweringen dienen evenwel gerelativeerd of zelfs tegengesproken te worden. Dit kan geïllustreerd worden met een advies over het recht op maatschappelijke bijstand. België wilde het recht van opvang van asielzoekers en het recht op maatschappelijke bijstand voor onderdanen van de lidstaten van de EU beperken. De Raad van State, afdeling wetgeving, merkte op dat '[v]oor zover de voorgestelde beperkingen, of althans sommige ervan, geacht zouden moeten worden een gevoelige verlaging mee te brengen van het niveau van bescherming dat door de geldende wetgeving geboden wordt, zou deze beperking, zoals reeds het geval geweest is bij eerdere wijzigingen van de wet van $\mathrm{I} 2$ januari 2007 , gerechtvaardigd moeten kunnen worden op basis van motieven die verband houden met het algemeen belang. Een dergelijke rechtvaardiging moet beantwoorden aan het evenredigheidsbeginsel, hetgeen betekent dat de maatregelen passend dienen te zijn, noodzakelijk voor het nagestreefde algemeen belang en evenredig sensu stricto.' Deze benadering, die naar de standstill verwijst, blijkt dus ook een evenredigheidstoets in te houden. ${ }^{\text {ir }}$ De evenredigheidstoets in het kader van de standstill heeft evenwel betrekking op de vraag of de verminderde bescherming gerechtvaardigd is, terwijl men in het andere geval nagaat of de actie of het ontbreken van actie van de overheid gerechtvaardigd kan worden in het licht van de vereiste sociale bescherming. In het laatste geval volstaat het dat de vereiste bescherming voor handen is, terwijl in het eerste geval elke aanzienlijke vermindering van de bescherming, ook al ligt die ruim boven de vereiste minimumbescherming, verantwoord zal moeten worden door de wetgever. Men zou dus kunnen argumenteren dat in sommige gevallen de verplichting tot standstill, een beperktere manoeuvreerruimte inhoudt voor de wetgever. Sommige auteurs merken dan ook terecht op dat 'de proportionaliteitstoets (...) meer mogelijkheden inhoudt voor de overheid om terug te keren op een bepaald beschermingsniveau, dan doorgaans werd aangenomen op grond van de klassieke theorie van het standstillbeginsel. ${ }^{{ }_{102}}$ Angst voor te actieve rechters is dus op zich geen reden om de proportionaliteitstoets te verwerpen en vast te houden aan het standstill-beginsel.

\section{Tussenbesluit}

2I. De Raad van State, afdeling wetgeving, heeft verschillende soorten schendingen van artikel 23 van de Grondwet (en in mindere mate van het ESH) vastgesteld.

IoI Merk op dat de Raad van State niet verwijst naar de verplichtingen van het individu, terwijl het Grondwettelijk Hof wel de nadruk hierop legt (zie infra $n^{\circ} 35$ ).

I02 B. Steen, 'Artikel 23 van de Grondwet en de rechtspraak van de Raad van State', in: W. Rauws en M Stroobant (ed.), Sociale en economische grondrechten, Antwerpen/Louvain-la-Neuve, Intersentia/ Anthemis, I3o. 
Ten eerste wordt er regelmatig opgemerkt dat het legaliteitsbeginsel, vervat in artikel 23 van de Grondwet, geschonden is. Daarnaast oppert de Raad van State ook in een beperkt aantal gevallen dat het standstill-beginsel geschonden is. Hij verkiest evenwel meestal om de vraag of de standstill geschonden is te omzeilen. Ten slotte heeft de Raad van State, afdeling wetgeving, (vooral, maar niet exclusief, in zaken die betrekking hadden op het recht op behoorlijke huisvesting) ook rechtstreeks onderzocht en vastgesteld dat de wet onvoldoende sociale bescherming bood. Op de grote recente sociale hervormingen, zoals de hervorming van de pensioenstelsels of de flexibilisering van de arbeidsvoorwaarden, hebben artikel 23 van de Grondwet of het ESH relatief weinig impact gehad in de adviespraktijk van de Raad van State, afdeling wetgeving. De reden is niet helemaal duidelijk, maar men zou kunnen aanvoeren dat de huidige Belgische wetgeving, ook na de recente hervormingen, meestal een afdoende sociale bescherming biedt. De menselijke waardigheid is niet in het geding. Er lijkt dan ook geen aanleiding om vaak in de adviespraktijk te verwijzen naar schendingen van artikel 23 van de Grondwet of het ESH. Benieuwd of een analyse van de rechtspraak tot dezelfde conclusie noopt.

\section{A posteriori juridische controle op naleving sociale en economische grondrechten}

22. Er heerst nog steeds een groot wantrouwen in de Belgische rechtspraak jegens de rechtstreekse toepassing van sociale en economische grondrechten. Dit wantrouwen is in eerste instantie ingegeven door de traditionele opvatting over de directe werking van deze bepalingen (I). Men kan evenwel vaststellen dat de rechtspraak van het Grondwettelijk Hof en de Raad van State in het objectieve contentieux vaak aan deze grondrechten toetst (2). Ze volgen daarbij hetzelfde stramien als de Raad van State, afdeling wetgeving: van legaliteitsbeginsel ${ }^{\mathrm{IO} 3}$ over standstill naar enkele arresten die aantonen dat aan sociale rechten rechtstreeks getoetst kan worden. In een aantal gevallen erkent de rechterlijke macht zelfs dat de sociale en economische grondrechten ook een subjectief recht kunnen bevatten (3). De vraag die daarbij rijst is welke de precieze draagwijdte is van economische en sociale grondrechten. Daarbij kan de 'rechtspraak' van het ESH-Comité een gids zijn (4).

\section{Terughoudende rechters en de problematiek van de 'directe werking'}

23. Traditioneel neemt de Belgische wetgever, alsook de rechtspraak en rechtsleer aan dat in de internationale verdragen erkende sociale en economische grondrechten slechts geleidelijk aan gerealiseerd moeten worden en geen 'directe' of 'rechtstreekse' werking hebben. ${ }^{104}$ Volgens de Belgische rechtspraak heeft een regel van

I03 Dit wordt hier niet verder uitgediept. Voor verwijzingen naar de rechtspraak van het Grondwettelijk Hof, zie de supra (nr. I4) vermelde adviezen 50623 \& 5I476 van de Raad van State.

I04 Zo leest men in de parlementaire voorbereiding dat 'de Verdragsluitende Staten zich niet verbinden de in het Verdrag neergelegde economische, sociale en culturele rechten onmiddellijk 
internationaal recht directe werking wanneer voldaan is aan een subjectieve en een objectieve voorwaarde. ${ }^{105}$ De subjectieve voorwaarde vereist dat de opstellers van het betrokken internationale instrument de bedoeling hebben gehad rechten of plichten voor particulieren te creëren. De objectieve voorwaarde houdt in dat de internationaalrechterlijke (verdrags)regel die rechten of verplichtingen toekent voldoende duidelijk, nauwkeurig en onvoorwaardelijk moet zijn. ${ }^{\text {106 }}$ Indien de internationale norm geen directe werking heeft, zal die in principe eerst omgezet moeten worden in de nationale rechtsorde om interne rechtsgevolgen te hebben. Ook voor artikel 23 van de Grondwet wordt meestal aangenomen dat het geen directe werking heeft, hoewel de term 'directe werking' voor een grondwetsartikel enigszins misleidend is aangezien het grondwetsartikel sowieso juridische werking heeft in de nationale rechtsorde. Er wordt - naar analogie met het internationaal recht - aangevoerd dat het niet de bedoeling was om subjectieve rechten toe te kennen (subjectief criterium). Bovendien is in die visie artikel 23 van de Grondwet op zich onvoldoende precies, duidelijk en nauwkeurig. Dat artikel bepaalt immers expliciet dat de voorwaarden voor de uitoefening door de wetgever moeten worden uitgewerkt (objectief criterium). Deze traditionele benadering wordt duidelijk verwoord en aangehangen in arresten van het Hof van Cassatie ${ }^{107}$ en van de Raad van State. ${ }^{108}$ Deze traditionele benadering wordt evenwel bekritiseerd door de recente rechtsleer. ${ }^{109}$ De meeste auteurs stellen vast dat er doorgaans meer belang wordt gehecht aan de objectieve voorwaarde. ${ }^{\text {Io }}$ Sommigen argumenteren dan ook dat internationale bepalingen als 'self-executing' kunnen worden beschouwd, op voorwaarde dat de norm voldoende duidelijk en precies is, zelfs indien dit zou ingaan tegen de wil van de partijen die

in hun volle omvang te bewerkstelligen', dat ze zich louter ertoe verbinden de algehele verwezenlijking van deze rechten als streefdoel te erkennen en met volledige gebruikmaking van de hun ter beschikking staande hulpbronnen en met alle passende middelen tot de verwezenlijking van dit te komen en dat bijgevolg 'niemand erbij gebaat zou zijn zich direct op de in deze akte neergelegde rechten te beroepen en hun toepassing voor de rechter af te dwingen.' Memorie van toelichting, Parl. St. Kamer I977-78, nr. I88/I, 5 .

I05 Cass. 2I april I983 (Thonon/Belgische Staat), R.W. I983-84, 2315-2317.

Io6 M. Bossuyt, "De inroepbaarheid van verdragsbepalingen of wat is er "rechtstreeks" aan de "rechtstreekse werking", in: D. Van Eeckhoutte en J. Wouters, Doorwerking van Internationaal Recht in de Belgische rechtsorde, Intersentia, 2006, III-II7; A. Vandaele en E. Claes, 'Naar een gradueel concept van directe werking van verdragsrecht en van internationaal gewoonterecht', in: D. Van Eeckhoutte en J. Wouters, Doorwerking van Internationaal Recht in de Belgische rechtsorde, Intersentia, 2006, (83) 84 et seq.

107 Cass. 2I april I983 (Thonon/Belgische Staat), R.W. 1983-84, 2315-2317; Cass. 20 december 1990 (Belgische staat/Najimi), Arr. Cass. I990-9I, 445 i.v.m. artikel I3.2 IVESCR; Cass. 26 mei 2008, (D.T.H.D.P Verrekenkas voor kinderbijslag v.z.w.), Arr. Cass. 2008, I3I9 i.v.m. artikelen 2.I, 9 en IO.3 IVESCR.

Io8 Rvs, afdeling bestuursrechtspraak, arrest van I4 januari I999, nr. 78153, TBP 2000, I63.

Io9 A. Vandaele en E. Claes, 'Naar een gradueel concept van directe werking van verdragsrecht en van internationaal gewoonterecht', in: D. Van Eeckhoutte en J. Wouters, Doorwerking van Internationaal Recht in de Belgische rechtsorde, Intersentia, 2006, (83) 84 et seq.

IIo J. Wouters, N. Hachez en P. De Man, 'Internationaal recht voor de praktizijn: hoe omgaan met handelingen van internationale instellingen en internationale rechtspraak', in: K. Lenaerts en J. Wouters (eds.), Internationaal and Europees Recht, Themiscahier No. 49, Brugge: Die Keure, 2008, 63; H. Vanderlinden, 'Effectiviteit van de sociale grondrechten in het Belgische recht, mythe of realiteit,' R.W. 2008-09, I205. 
het verdrag hebben gesloten. ${ }^{111}$ Als dat klopt, rijst de vraag eveneens of men eenzelfde evolutie kan ontwaren voor de 'directe' werking van Belgische grondwettelijke normen met betrekking tot sociale en economische rechten. Mijn inziens heeft de Franse Raad van State alvast terecht het subjectief criterium afgezwakt. ${ }^{\text {II2 }}$

\section{Rechtstreekse toepassing in het objectief contentieux}

24. De theorie dat de wetgever moet optreden vooraleer de sociale en economische grondrechten zoals vastgelegd in internationale verdragen en de Grondwet enig effect kunnen sorteren, wordt in de Belgische juridische orde alvast getemperd door de rechtspraak van de Raad van State en het Grondwettelijk Hof in het objectief contentieux. ${ }^{113}$ Zowel de Raad van State ${ }^{114}$ als het Grondwettelijk Hof ${ }^{115}$ heeft aanvaard dat zijn taak erin bestaat om te toetsen of de Belgische wetgeving ${ }^{\text {I16 }}$ in overeenstemming is met de doelstelling vervat in de duidelijke en precieze rechtsregels van de internationale verdragen inzake economische, sociale en culturele rechten. Maar hoewel men het over dit principe eens is, wordt nog vaak bij de toepassing ervan geschermd met de vage bewoordingen van de sociale en economische rechten. Zo heeft de Raad van State in een recent arrest nog vastgesteld dat artikel 6 IVESCR (recht op arbeid) te vaag is om rechtstreeks toegepast te kunnen worden. ${ }^{\text {I7 }}$ Ook het Grondwettelijk Hof wijst er bijvoorbeeld op dat 'de vermelde doelstellingen van een duurzame ontwikkeling niet louter en alleen op basis van [artikel 7 bis, van de Grondwet] met de met het oog op een rechterlijke toetsing vereiste nauwkeurigheid kunnen worden bepaald, wat het beleidsdomein van de ruimtelijke ordening

III H. Vanderlinden, 'Effectiviteit van de sociale grondrechten in het Belgische recht, mythe of realiteit,' R.W. 2008-09, I205.

II2 Y. Aguila, 'L'effet direct des conventions internationales: une nouvelle grille d'analyse', AJDA 20I2, 729 waarin verwezen wordt naar Conseil d'Etat, arrêt d'assemblée, II april 20I2, GISTI et FAPIL (req. $\mathrm{N}^{\circ} 322326,735$ ). De subjectieve test vereist niet langer dat de Staat subjectieve rechten wou toekennen maar dat de bepaling 'niet als exclusief voorwerp de relaties tussen Staten regelt' ('une stipulation est d'effet direct lorsqu'elle "n'a pas pour objet exclusif de régir les relations entre Etats" et “ ne requiert l'intervention d'aucun acte complémentaire pour produire des effets à l'égard des particuliers"').

II3 In dit contentieux is het subjectieve criterium niet aan de orde. Het debat gaat niet over de toekenning van subjectieve rechten aan burgers, maar over de verenigbaarheid van regels die door de nationale wetgever zijn opgesteld met de hogere rechtsnormen. Het is de wettigheid van de norm die wordt gecontroleerd. H Vanderlinden, 'Effectiviteit van de sociale grondrechten in het Belgische recht, mythe of realiteit,' R.W. 2008-09, I209.

II4 Rvs, arrest van 6 september 1989 , nr. 32989 (i.v.m. het recht op kosteloos lager onderwijs vervat in artikel 13, 2, a, IVESCR): 'dat het er aldus niet op aankomt te weten of het Verdrag inzake economische, sociale en culturele rechten aan particulieren subjectieve rechten heeft verleend waarop ze zich vóór de rechtbanken kunnen beroepen, maar wel te toetsen of de Belgische wetgeving in overeenstemming is met de doelstelling vervat in de duidelijke en precieze rechtsregel van artikel I3, 2, a, van het Verdrag'.

II5 Grondwettelijk Hof, nr. Io6/2003, 22 juli 2003.

II6 Het Grondwettelijk Hof toetst de formele wetten, decreten en ordonnanties aan hogere wetgeving. De Raad van State toetst de besluiten aan de hogere wetgeving.

II7 Rvs, afdeling bestuursrechtspraak, arrest van 27 juni 20II, nr. 2I4.I83. In dezelfde zin Rvs, afdeling bestuursrechtspraak, arrest van 27 november 2006, nr. I65.126. In een andere zaak wordt gesteld dat het recht op bescherming van een gezond leefmilieu geen directe werking heeft (Rvs, afdeling bestuursrechtspraak, arrest 29 juni 2010, nr. 206.069). 
betreft.' ${ }^{118}$ Ook het programmatische karakter van de bepalingen zou erop kunnen wijzen dat de rechter moeilijk aan deze bepaling kan toetsen. Om aan dit laatste bezwaar tegemoet te komen past het Grondwettelijk Hof evenwel de 'truc' van de standstill-verplichting toe (a.). Daarnaast kan men bovendien vaststellen dat er ook vaak rechtstreeks getoetst wordt zonder een beroep te doen op de standstill (b.).

\section{a. De 'truc' van de 'standstill'-verplichting.}

25. Het standstill-beginsel houdt in dat regels die het bestaande beschermingsniveau van sociale en economische grondrechten zonder reden van algemeen belang zouden afbouwen, onverenigbaar zijn met dit grondrecht ${ }^{119}$ (zie ook supra nr. 15). Het Grondwettelijk Hof formuleert het als volgt: 'artikel 23 van de Grondwet [...] houdt een standstill-verplichting in die de bevoegde wetgever verbiedt het beschermingsniveau aanzienlijk te verminderen zonder dat daartoe redenen van algemeen belang bestaan.' ${ }^{\text {'20 }}$ Op die manier wordt de progressiviteit van sociale grondrechten benadrukt. Het verplicht de overheid niet om (onmiddellijk) bijkomende stappen te nemen en het niveau van rechtsbescherming te verhogen, maar het verhindert wel dat de bestaande rechtsbescherming wordt afgebouwd. ${ }^{\text {221 }}$ Het standstill-beginsel wordt vaak beschouwd als een manier om de sociale en economische grondrechten, bij gebreke aan directe werking, alsnog een juridische betekenis te geven. ${ }^{\mathrm{I} 22}$

26. Het standstill-beginsel vindt men terug in zowel de rechtspraak van het Grondwettelijk Hof als in de rechtspraak van de Raad van State. Het Grondwettelijk Hof heeft dit beginsel enkel expliciet aanvaard met betrekking tot het recht op sociale bijstand en het recht op een gezond leefmilieu. ${ }^{\mathrm{I} 23}$ Met betrekking tot het recht op sociale bijstand heeft het Grondwettelijk Hof nog geen schending van het standstill-beginsel vastgesteld. ${ }^{124}$ Wel heeft het Grondwettelijk Hof reeds geoordeeld dat een regeling die een voor bepaalde sociaal verzekerden minder gunstige regeling

II8 Grondwettelijk Hof, nr. 75/20II, I8 mei 20II, B. 6. Dit wordt opgemerkt nadat het Grondwettelijk Hof bevestigde dat het niet rechtstreeks aan artikel 7 bis van de Grondwet kan toetsen, maar er wel rekening mee kan houden bij de interpretatie van andere grondwetsbepalingen.

II9 G. Maes, 'Twintig jaar sociale grondrechten in de grondwet', in: W. Rauws en M. Stroobant (ed.), Sociale en economische grondrechten, Antwerpen/Louvain-la-Neuve, Intersentia/Anthemis, I5I.

I20 Grondwettelijk Hof, nr. I35/20II, 27 juli 20II, B.5.I.

I2I G. Maes, 'Twintig jaar sociale grondrechten in de grondwet', in: W. Rauws en M. Stroobant (ed.), Sociale en economische grondrechten, Antwerpen/Louvain-la-Neuve, Intersentia/Anthemis, 152.

I22 Zie bijvoorbeeld de argumentatie van de verzoekers in Rvs, afdeling bestuursrechtspraak, arrest nr. I02.5IO van I4 januari 2002: 'indien die bepalingen niet rechtstreeks in de Belgische rechtsorde van toepassing zijn, dan stellen zij toch een standstill in, op grond waarvan de Staat geen reglementering meer kan invoeren die tegen die bepalingen in gaat.'

I23 M. Bossuyt, 'Artikel 23 van de grondwet in de rechtspraak van het Grondwettelijk Hof', in: W. Rauws en M. Stroobant (ed.), Sociale en economische grondrechten, Antwerpen/Louvain-laNeuve, Intersentia/Anthemis, 6r. Voor een recent voorbeeld in zake sociale bijstand zie arrest nr. I35/20II van 27 juli 20II, B. 9.5.

I24 M. Bossuyt, 'Artikel 23 van de grondwet in de rechtspraak van het Grondwettelijk Hof', in: W. Rauws en M. Stroobant (ed.), Sociale en economische grondrechten, Antwerpen/Louvain-la-Neuve, Intersentia/Anthemis, 63. Zie bijvoorbeeld Grondwettelijk Hof, nr. 99/2010, I6 september 20Io, B.4.7; Grondwettelijk Hof, nr. I35/20II, 27 juli 20II, B. 9.5. 
invoerde, een schending uitmaakte van het gelijkheidsbeginsel. ${ }^{125}$ De Raad van State, afdeling bestuursrechtspraak, zit op dezelfde lijn als het Grondwettelijk Hof: het bestaan van het standstill-beginsel wordt erkend, ook in sociale materies, maar een schending daarvan werd tot op heden nog niet aangenomen voor wat betreft het recht op sociale bijstand. ${ }^{\mathrm{I} 26}$

27. In feite heeft het standstill-beginsel weinig impact op de rechtspraak, althans voor zover getoetst wordt aan economische en sociale grondrechten. Het is vooral in verband met het recht op een gezond leefmilieu dat dit beginsel een belangrijke rol speelt en tot de vaststelling van schendingen leidt. ${ }^{127}$ De rechtspraak in milieuaangelegenheden wijst echter op een aantal onduidelijkheden die de toepassing van dit beginsel met zich meebrengt.

Zo rijst de vraag of bij de beoordeling vertrokken moet worden van een referentienorm, i.e. de bestaande rechtsregels, of van een referentietoestand, i.e. de bestaande feitelijke toestand. De Raad van State lijkt alvast te vertrekken vanuit de referentienormen. ${ }^{128}$ Deze visie mag er evenwel niet toe leiden dat de grondrechten weliswaar in theorie beschermd zijn via wetgevende normen, maar in de praktijk elke daadwerkelijke betekenis verliezen omdat de normen niet geïmplementeerd worden. Men kan dus niet in abstracto uitsluiten dat in bepaalde omstandigheden ook rekening zal moeten worden gehouden met de feitelijke situatie.

Ook de vraag of vergeleken moet worden met het 'bestaande beschermingsniveau' of met 'het beschermingsniveau dat wordt geboden op het ogenblik van de inwerkingtreding van artikel 23 van de Grondwet' is aanleiding voor controverse. Zowel de Raad van State als het Grondwettelijk Hof lijkt vandaag aan te nemen dat vertrokken moet worden van een mobiel referentieogenblik (het bestaande beschermingsniveau). ${ }^{\mathrm{I} 2}$

Ten slotte rijst de vraag of met het standstill-effect alleen rekening moet worden gehouden wanneer de overheid 'nalaat de rechten van de burgers behoorlijk te

I25 Grondwettelijk Hof, nr. 66/20I2, 24 mei 20I2, B.4.2. Dat gekozen werd om terug te grijpen naar het gelijkheidsbeginsel en niet de standstill valt te verklaren doordat de prejudiciële vraag van de bodemrechter betrekking had op het gelijkheidsbeginsel.

I26 Zie bijvoorbeeld Rvs, afdeling bestuursrechtspraak, arrest nr. 209222 van 27 mei 20Io: 'Te dezen maakt de verzoekende partij niet aannemelijk dat de gewijzigde tarieven en schalen met betrekking tot het Pensioenfonds van de Dienst voor overzeese sociale zekerheid als een aanzienlijke vermindering van het beschermingsniveau kan worden beschouwd.' Zie ook bijvoorbeeld Rvs, arrest nr. I02.5Io van I4 januari 2002 ( geen schending van het recht op arbeid en billijke arbeidsvoorwaarden).

I27 Zie bijvoorbeeld Grondwettelijk Hof, nr. I37/2006, I4 september 2006.

I28 B. Steen, 'Artikel 23 van de Grondwet en de rechtspraak van de Raad van State', in W. Rauws en M. Stroobant (ed.), Sociale en economische grondrechten, Antwerpen/Louvain-la-Neuve, Intersentia/ Anthemis, I25 met verwijzing naar Rvs, afdeling bestuursrechtspraak, arrest nr. I40730 van 26 februari 2005 en arrest nr. I854I5 van I6 juli 2008.

I29 Zie bijvoorbeeld Rvs, afdeling bestuursrechtspraak, arrest nr. I66439 van 9 januari 2007 en Grondwettelijk Hof, nr. 99/20I0, I6 september 20I0. Over dit laatste arrest merkt Jan Theunis het volgende op: 'Opmerkelijk is dat het Hof spreekt over het "bestaande beschermingsniveau", terwijl het in eerdere rechtspraak inzake het recht op juridische bijstand gewaagde van "het beschermingsniveau dat wordt geboden op het ogenblik van de inwerkingtreding van artikel 23 . Daardoor tekent zich een gelijkschakeling af met de draagwijdte van de standstill-verplichting in andere domeinen".' J. Theunis, 'De toetsing aan grondrechten door het Grondwettelijk HofOverzicht van rechtspraak 20I0', TBP 20I2/I, 35. 
beschermen' of anders uitgedrukt, in het geval op de overheid een positieve verplichting rust om maatregelen te nemen om een bepaald grondrecht te verwezenlijken. Dit is in milieuzaken alvast de visie van de algemene vergadering van de Raad van State in het arrest Coomans van 17 november 2008..$^{130}$ Dit bevestigt het oordeel van sommige rechtsgeleerden dat de Raad van State de directe werking van artikel 23 van de Grondwet aanvaardt in de mate dat die bepaling belet dat de overheid een bepaald grondrecht inperkt (of anders gezegd: artikel 23 zou rechtstreekse werking hebben voor zover de overheid een negatieve verplichting schendt door zijn optreden). ${ }^{\text {I3 }}$ Deze benadering stuit evenwel op het bezwaar dat het niet altijd eenvoudig is om na te gaan of er sprake is van een positieve of negatieve verplichting. De Raad van State illustreert dit zelf onmiddellijk in het arrest Coomans door te beklemtonen dat in het concrete geval niet moet worden onderzocht of het gaat om een inmenging door de overheid in het grondrecht dan wel of de overheid heeft nagelaten de burgers voldoende te beschermen. De Raad gaat immers direct na of de bestreden maatregelen wel proportioneel zijn en geen ongerechtvaardigde aantasting uitmaken van het recht op de bescherming van een gezond leefmilieu. Hiermee voert de Raad van State de proportionaliteitstoets door die ook doorgevoerd wordt wanneer wordt nagegaan of andere grondrechten (waarvan aangenomen wordt dat ze directe werking hebben) zijn geschonden. ${ }^{132}$ Hoewel de Raad aldus het standstillbeginsel erkent, relativeert hij eigenlijk het belang ervan. Door aan te geven dat het onderscheid tussen positieve en negatieve verplichtingen in casu niet relevant is, geeft de Raad impliciet aan dat bij de toetsing aan grondrechten vooral steeds een proportionaliteitstoets gemaakt moet worden. Het standstill-beginsel is dan slechts één uitdrukkingsvorm van die proportionaliteitstoets, en de toepassing van dat beginsel dient bovendien beperkt te worden tot de positieve verplichtingen. Het is niet nodig om naar de standstill te verwijzen indien men een volledige toetsing doorvoert. ${ }^{133}$ In het concrete geval bood de conceptuele gelijkschakeling van het recht op een gezond leefmilieu met andere grondrechten alvast geen ruimere rechtsbescherming: de Raad was van oordeel dat het billijk evenwicht tussen het algemeen belang en de individuele belangen van de verzoekers niet werd verbroken. ${ }^{134}$ Wat het arrest Coomans tot een mijpaalarrest maakt, is de aanname dat in het objectief contentieux rechtstreeks aan het recht op een gezond leefmilieu van artikel 23 van de Grondwet wordt getoetst, of het nu om een positieve of een negatieve verplichting gaat zonder dat daarbij een beroep dient gedaan te worden op de 'truc' van de standstill. De vraag

I30 Rvs, afdeling bestuurrechtspraak, arrest nr. I87998 van I7 november 2008.

I3I M. Pâques en B. Jadot, 'Diversité des dispositions qui font de l'environnement l'objet d'un droit fondamental', in: L'environnement, objet d'un droit fondamental, Amén, 2008, Numéro spécial, 209.

I32 B. Steen, 'Artikel 23 van de Grondwet en de rechtspraak van de Raad van State', in: W. Rauws en M. Stroobant (ed.), Sociale en economische grondrechten, Antwerpen/Louvain-la-Neuve, Intersentia/ Anthemis, I30.

I33 Indien de proportionaliteitstoets niet de toets die eigen is aan de standstill omvat, zou het in tegenstelling tot wat de Raad beweert, wel noodzakelijk zijn om na te gaan of er sprake is van een negatieve dan wel positieve verplichting. Er zou immers sprake zijn van twee verschillende afwegingen die elkaar niet volledig overlappen.

I34 Rvs, afdeling bestuurrechtspraak, arrest nr. I87998 van I7 november 2008, I8.5. 
rijst in welke mate deze redenering ook kan doorgetrokken worden voor de andere sociale en economische grondrechten van artikel 23 van de Grondwet.

\section{b. Rechtstreekse bescherming en de eigen verplichtingen}

28. In een aantal gevallen heeft de Raad van State of het Grondwettelijk Hof rechtstreeks getoetst aan de sociale en economische grondrechten zonder een beroep te doen op de standstill. Impliciet wordt er dan van uitgegaan dat het grondrecht voldoende duidelijk en precies is om aan getoetst te worden. Beide hoven gaan dan als het ware op zoek naar wat die bescherming inhoudt, rekening houdend met het feit dat het individu ook plichten heeft. Een evenredigheidstoets tussen het algemeen belang en het individueel belang, rekening houdend met de plichten van het individu, is daarbij net als in het arrest Coomans cruciaal. Om dit te illustreren onderzoeken we verder drie van de in artikel 23 van de Grondwet opgesomde rechten: het recht op een behoorlijke huisvesting (A), het recht op arbeid en op de vrije keuze van beroepsarbeid (B) en het recht op sociale zekerheid en bescherming van de gezondheid (C). Uiteindelijk blijkt uit deze analyse dat er nog veel onzekerheid is (D).

\section{A Recht op een behoorlijke huisvesting}

29. Het recht op een behoorlijke huisvesting biedt waarschijnlijk de meest treffende voorbeelden van een rechtstreekse toetsing aan een sociaal grondrecht, waarbij zowel het Grondwettelijk Hof als de Raad van State zich vooral toespitst op een afweging van de in het geding zijnde belangen. Op die manier tekenen zich via jurisprudentiële weg de contouren af van wat men het recht op een behoorlijke huisvesting noemt. In die situaties valt het op hoe de juridische analyse parallel loopt met die voor andere klassieke grondrechten: men gaat na of de maatregel verenigbaar is met het grondrecht en daarbij staat een belangenafweging centraal. De vraag of er sprake is van een negatieve of positieve verplichting en of men te maken heeft met een sociaal-economisch grondrecht dan wel een burgerlijk of politiek grondrecht verdwijnt daarbij vaak op de achtergrond. Belangrijk is wel dat, mede geïnspireerd door de tekst van artikel 23 van de Grondwet, ook duidelijk rekening wordt gehouden met de plichten van het individu bij de afweging tussen het individueel en het algemeen belang. Dit is een evolutie die ook de vaststelling van positieve verplichtingen bij burgerlijke en politieke rechten in de toekomst meer en meer zou kunnen beïnvloeden.

30. Zo oordeelt het Grondwettelijk Hof in arrest Ior/2008 dat een regeling waarbij de sociale huurovereenkomst ontbonden kan worden zonder rechterlijke tussenkomst afbreuk doet aan de woonzekerheid gegarandeerd door artikel 23 van de Grondwet. ${ }^{135}$ Het Grondwettelijk Hof erkent in eerste instantie dat het Hof op het vlak van het huisvestingsbeleid het oordeel van de gewestwetgevers betreffende het algemeen belang dient te eerbiedigen, tenzij dat oordeel kennelijk onredelijk is. ${ }^{1{ }^{6}} \mathrm{Er}$

I35 Grondwettelijk Hof, nr. IoI/2008, Io juli 2008, B. 23.2.

I36 Hierbij verwijst het Grondwettelijk Hof zelf naar arrest nr. 33/2007, B.5.3; Grondwettelijk Hof, nr. 62/2007, I8 april 2007, B.5·3; Grondwettelijk Hof, nr. 155/2007, I9 december 2007, B.6. 
is aldus in principe een grote appreciatiemarge voor de overheid. Die beoordelingsvrijheid is echter minder ruim wanneer dat huisvestingsbeleid voor een bepaalde categorie van personen het verlies van hun woonst kan teweegbrengen, hetgeen immers als een van de meest verregaande inmengingen in het recht op eerbiediging van de woning wordt beschouwd. ${ }^{137}$ Vermits de verhuurders van sociale woningen niet verstoken zijn van middelen om op te treden tegen huurders die weigeren hun verplichtingen na te komen, is het niet noodzakelijk om de sociale huurders de waarborg te ontnemen die wordt gevormd door het optreden van de rechter vóór een eventuele beëindiging van de huurovereenkomst. De conclusie is dan ook dat de mogelijkheid voor de verhuurder om de huurovereenkomst te beëindigen zonder voorafgaande rechterlijke controle, met toepassing van een uitdrukkelijk ontbindend beding, niet evenredig is met het doel de leefbaarheid in de sociale woonwijken te waarborgen. ${ }^{13^{8}} \mathrm{Na}$ uiteengezet te hebben waarom een a posteriori rechterlijke controle voor de ontbinding niet volstaat, ${ }^{139}$ besluit het Grondwettelijk Hof 'dat de mogelijkheid om een uitdrukkelijk ontbindend beding op te nemen in de huurovereenkomst, in het nadeel van de sociale huurders, niet redelijk verantwoord is ten opzichte van het recht op een behoorlijke huisvesting zoals gewaarborgd door artikel 23 van de Grondwet.' Het is hierbij opvallend dat het Grondwettelijk Hof de maatregel rechtstreeks toetst aan artikel 23 van de Grondwet, zonder enige verwijzing naar andere grondwetsartikelen en zonder te verwijzen naar het standstillbeginsel. ${ }^{140}$ Het Grondwettelijk Hof heeft zelf aangegeven in welke gevallen een dergelijke rechtstreekse toetsing tot een mogelijke schending kan leiden: in geval een bepaalde reglementering voor een bepaalde kwetsbare categorie van personen het verlies van hun woonst kan teweegbrengen, zal de beoordelingsvrijheid van de wetgever minder ruim zijn en de proportionaliteitstoets aldus strikter. ${ }^{14 \mathrm{I}}$ In de andere gevallen dient het Grondwettelijk Hof het oordeel van de wetgever betreffende het algemeen belang te eerbiedigen, tenzij dat oordeel kennelijk onredelijk is..$^{142}$

3r. Bij de belangenafweging dient ook rekening gehouden te worden met de plichten van het individu. Dit blijkt uit datzelfde arrest Ior/2008 dat betrekking had op de vraag of de verplichting om zijn bereidheid aan te tonen om Nederlands te leren om in aanmerking te komen voor een sociale huurwoning verenigbaar was met artikel 23 van de Grondwet. Het Grondwettelijk Hof oordeelde dat er verplichtingen

I37 Hierbij verwijst het Grondwettelijk Hof in B.23.3 naar EHRM, I3 mei 2008, McCann t. Verenigd Koninkrijk, § 50.

I38 Grondwettelijk Hof, nr. Ior/2008, ro juli 2008, B. 25.2.

I39 Grondwettelijk Hof, nr. IOI/2008, ro juli 2008, B.25.3. 'Het is juist dat een rechterlijke controle steeds a posteriori kan plaatsvinden, nadat de huurovereenkomst werd beëindigd met toepassing van een uitdrukkelijke ontbindende voorwaarde. Het optreden van de rechter op dat ogenblik, wanneer de huurder zijn woning is kwijtgeraakt en deze aan een andere persoon kan zijn toegewezen, weegt echter niet op tegen de ontstentenis van het optreden van de rechter om de overeenkomst te beëindigen omdat, wanneer zou blijken dat de verhuurder een beoordelingsfout heeft gemaakt, niet kan worden gewaarborgd dat de huurder wiens woning werd ontnomen, erin kan terugkeren.'

I40 Dit is des te opvallender aangezien de eisers wel daarnaar verwijzen.

I4I Grondwettelijk Hof, nr. I0I/2008, Io juli 2008, B. 23.3; Grondwettelijk Hof, nr. I30/2008, I september 2008, B. I8.

I42 Grondwettelijk Hof, nr. Ior/2008, io juli 2008, B. 23.3; Grondwettelijk Hof, nr. I30/2008, I september 2008 , B. 18 . 
kunnen worden opgelegd om toegang te verkrijgen tot economische, sociale en culturele rechten. Die verplichtingen moeten volgens het Grondwettelijk Hof verbonden zijn met de algemene doelstelling die is ingeschreven in het eerste lid van artikel 23, namelijk eenieder in staat te stellen een menswaardig leven te leiden door het genot van de rechten die zijn opgesomd in het derde lid. ${ }^{43}$ De decreetgever kon oordelen dat de voorwaarde met betrekking tot de bereidheid om Nederlands te leren teneinde een elementair niveau van taalbeheersing te bereiken, kon worden beschouwd als een 'overeenkomstige plicht' in de zin van artikel 23 van de Grondwet. Het is immers aannemelijk dat 'de bereidheid om het Nederlands aan te leren aldus een middel [is] om de betrokkenheid van de huurder te verhogen om tezamen met de verhuurder een behoorlijke sociale huisvesting tot stand te brengen', in het bijzonder in de wijken waar personen van verschillende origine samenleven. ${ }^{\mathrm{I} 4} \mathrm{Het}$ Grondwettelijk Hof was dan ook van mening dat deze voorwaarde bestaanbaar was met artikel 23 van de Grondwet. ${ }^{145}$

32. Ook in talloze andere zaken die betrekking hebben op het recht op een behoorlijke huisvesting weegt het Grondwettelijk Hof in essentie de verschillende belangen tegen elkaar af zonder te benadrukken dat artikel 23 van de Grondwet voornamelijk sociale en economische grondrechten beschermt die een aparte typologie of juridische redenering vereisen. Het betreft dan wel meestal zaken waarin een schending aangevoerd wordt van een zogenoemd klassiek grondrecht. ${ }^{146}$ Typisch daarvoor zijn de zaken waarbij het eigendomsrecht in conflict komt met het recht op huisvesting. ${ }^{\text {I7 }}$ Zo heeft het Grondwettelijk Hof in arrest 105/2000 een bepaling van de

I43 Grondwettelijk Hof, nr. Ior/2008, Io juli 2008, B. 33.2. Zie ook Grondwettelijk Hof, nr. I35/20II, 27 juli 20II, B. 8.3.2 en verder.

I44 Het Grondwettelijk Hof verduidelijkte dit als volgt: 'B 34.2 De verplichting om zijn bereidheid aan te tonen om Nederlands te leren, is niet onevenredig met dat doel omdat zij alleen betrekking heeft op een elementaire kennis van de taal, omdat kosteloos taallessen aan de betrokken personen worden aangeboden (Parl. St., Vlaams Parlement, 2005-2006, nr. 824/I, p. Ig), omdat de betrokkenen niettemin vrij zijn om op een andere manier hun bereidheid aan te tonen om Nederlands te leren (ibid.) en omdat hun geen enkele resultaatsverbintenis kan worden opgelegd, zodat noch de effectieve taalkennis, noch het gebruik van de taal, nadat lessen werden gevolgd of een andere leervorm werd gebruikt, door de verhuurder kunnen worden geëist of gecontroleerd (ibid., p. I6).'

I45 Grondwettelijk Hof, nr. I0I/2008, io juli 2008, B. 35: 'B.35. Onder voorbehoud dat eventuele sancties, in geval van weigering om Nederlands te leren of om het inburgeringstraject te volgen, evenredig zijn met de hinder of de last die door die weigering is veroorzaakt, en dat zij de opzegging van de huurovereenkomst enkel kunnen verantwoorden mits een voorafgaande rechterlijke controle, zijn die voorwaarden die aan de kandidaat-huurders en huurders van een sociale woning worden opgelegd, niet onbestaanbaar met artikel 23 van de Grondwet, al dan niet in samenhang gelezen met de in de middelen vermelde verdragsbepalingen, en geven zij geen aanleiding tot verschillen in behandeling die onbestaanbaar zijn met de artikelen Io en II van het Grondwet.'

I46 Het recht op privacy is een ander grondrecht dat vaak aan de orde is. Zie bijvoorbeeld Grondwettelijk Hof, nr. 69/2005, 20 april 2005: 'Het kan immers worden verantwoord dat, om elkeen het in artikel 23 van de Grondwet vastgelegde recht op een behoorlijke huisvesting te waarborgen, de ordannonatiegever de overheid machtigt om de effectieve bewoning na te gaan van een onroerend goed waarvoor aanwijzingen bestaan dat het zou kunnen leegstaan. Zulk een maatregel kan niet worden beschouwd als een onevenredige inmenging in het recht op eerbiediging van het privé-leven, van het gezinsleven en van de woning van de betrokken personen.'

I47 Grondwettelijk Hof, nr. I30/2008, I september 2008, B. I8; Grondwettelijk Hof, nr. 91/2010, 29 juli 2010, B.4.6.I en B. 7.2 
Brusselse Huisvestingscode gedeeltelijk vernietigd voor zover de gerechtelijke buitenbezitstelling mogelijk was van woningen die onafhankelijk van de wil van de eigenaar leeg stonden. ${ }^{148}$ Daarentegen maakte het openbaar beheersrecht van de Brusselse Huisvestingscode geen schending uit van het recht op eigendom in arrest $n^{\circ} 69 / 2005$, waarbij het Grondwettelijk Hof expliciet verwees naar artikel 23 van de Grondwet om tot die conclusie te komen. ${ }^{\text {I49 }}$ Vooraleer de proportionaliteit van de maatregel grondig te onderzoeken, benadrukte het Grondwettelijk Hof zelfs dat de doelstelling om op een efficiënte manier het woningaanbod op de Brusselse woonmarkt te vergroten zich omwille van artikel 23 aan de ordonnantiegever opdrong. Momenteel is ook een zaak hangend bij het Grondwettelijk Hof waarbij de vraag wordt gesteld of de zogenoemde sociale lasten van het grond- en pandendecreet, die van rechtswege opgelegd worden aan private actoren, geen schending uitmaken van het eigendomsrecht. ${ }^{150}$ De vraag rijst onder meer of een gedwongen bijdrage van private actoren tot de realisatie van sociale woningen en appartementen, die van rechtswege wordt opgelegd als sociale last verbonden aan elke bouw- of verkavelingsvergunning voor een project dat een wettelijk bepaalde minimale omvang heeft, de toets van het Europees recht doorstaat. ${ }^{151}$ Het Grondwettelijk Hof heeft alvast een aantal prejudiciële vragen aan het Hof van Justitie gesteld, zodat men kan vermoeden dat dit ook aanleiding zal geven tot een interpretatie van het Handvest van de grondrechten. ${ }^{152}$

\section{B Recht op arbeid}

33. Artikel 23 , derde lid, $I^{\circ}$ verwijst naar het recht op arbeid en op de vrije keuze van beroepsarbeid in het raam van een algemeen werkgelegenheidsbeleid dat onder meer gericht is op het waarborgen van een zo hoog en stabiel mogelijk werkgelegenheidspeil, het recht op billijke arbeidsvoorwaarden en een billijke beloning, alsmede

I48 Grondwettelijk Hof, nr. I05/2000, 25 oktober 2000, B. I3: 'Echter, indien de beoogde situaties die zijn van personen met een eigendomsrecht of met andere zakelijke rechten op onbewoonde en bewoonbare woningen, van wie de woning onbewoond is in de gevallen vermeld in het bepaalde onder $3^{\circ}$ en $4^{\circ}$ van artikel 80 , tweede lid, zijn de aangewende middelen niet relevant ten opzichte van de beoogde doelstelling van het verbeteren van de huisvesting, aangezien ze raken aan woningen die als bewoonbaar moeten worden beschouwd, en ze zijn niet even redig met het doel van het bevorderen van de sociale huisvesting wanneer de leegstand onafhankelijk is van de wil van de personen in kwestie.' De eisers voerden een schending van het gelijkheidsbeginsel aan (en niet van het recht op eigendom) omdat het niet redelijk verantwoord was de eigenaar van een onbewoonbaar verklaarde woning gelijk te stellen met de eigenaar van een onderhouden woning die, om toelaatbare redenen, niet bewoond was.

I49 Grondwettelijk Hof, nr. 69/2005, 20 april 2005, B. I7.I0: 'Gelet op wat voorafgaat en rekening houdend met het bijzondere gewicht dat door de Grondwetgever zelf aan het recht op een behoorlijke huisvesting is verleend, doen de bestreden bepalingen vanwege hun aard en vanwege de geboden waarborgen niet op onevenredige wijze afbreuk aan de rechten van de betrokken eigenaars.' Zie ook J. Sohier, 'La cour constitutionnelle, juge de la conciliation des droits fondamentaux: le droit de propriété face au droit au logement', in: Liège, Strasbourg, Bruxelles: parcours des droits de l'homme. Liber amicorum Michel Melchior, 20I0, Anthemis, I99-2I4.

I50 Grondwettelijk Hof, nr. I50/2010, 6 april 20II, B. 38.

I5I Grondwettelijk Hof, nr. I50/20I0, 6 april 20II, dispositief.

I52 Zie ook Grondwettelijk Hof, nr. I49/20Io, 6 april 20II, waarbij het Grondwettelijk Hof een prejudiciële vraag heeft gesteld in verband met de regelgeving met betrekking tot het 'wonen in eigen streek' om sociale verdringing te vermijden. 
het recht op informatie, overleg en collectief onderhandelen. Ook aan deze rechten werd (al dan niet via het ESH) door de Raad van State ${ }^{153}$ en het Grondwettelijk Hof ${ }^{154}$ rechtstreeks getoetst.

Zo oordeelt het Grondwettelijk Hof in arrest 29/20Io dat het recht op de vrije keuze van beroepsarbeid niet geschonden is. ${ }^{155}$ Door verzoekers werd aangevoerd dat de wet de verplichting oplegt om het eHealth-platform ${ }^{156}$ te gebruiken, terwijl bepaalde opdrachten die eraan zijn toevertrouwd, tegen vergoeding zouden kunnen worden uitgevoerd door een private onderneming. Het Grondwettelijk Hof stelt dat de bevoegde wetgever over een ruime beoordelingsvrijheid beschikt. Het Hof zou de maatregelen alleen kunnen afkeuren wanneer zij voortvloeien uit een kennelijk onredelijk oordeel. Gelet op de aard van de aan het eHealth-platform toegekende opdrachten en het privacygevoelig karakter van de daarin betrokken gegevens kunnen de aangevoerde beperkingen niet als kennelijk onredelijk of onevenredig worden beschouwd ten aanzien van de doelstelling, die erin bestaat de uitwisseling van gezondheidsgegevens op een maximaal beveiligde wijze te laten plaatsvinden. Het recht op de vrije keuze van beroepsarbeid was niet geschonden. In dit arrest zitten alle elementen vervat die de benadering van het Grondwettelijk Hof typeren voor de rechten vermeld in artikel 23 , derde lid, $\mathrm{I}^{\circ}$ zoals het recht op arbeid en een billijke beloning, ${ }^{157}$ het recht op vrije keuze van beroepsarbeid ${ }^{158}$ en het recht op informatie, overleg en collectief onderhandelen: ${ }^{59}$ het Grondwettelijk Hof benadrukt steeds weer dat het recht op arbeid geen absoluut karakter heeft ${ }^{160}$ en dat de bevoegde wetgever over een ruime beoordelingsvrijheid beschikt en slecht de genomen maatregelen kan afkeuren wanneer zij voortvloeien uit een 'kennelijk onredelijk oordeel'. ${ }^{16 \mathrm{I}}$

Ook de Raad van State toetst soms rechtstreeks aan bepaalde aspecten van het recht op arbeid. In een arrest van 2008 stelt de Raad van State enkele maanden voor

I53 Zie bijvoorbeeld Rvs, afdeling bestuursrechtspraak, arrest nr. 59163 van 24 april I996; Rvs, afdeling bestuursrechtspraak, arrest nr. I30492 van 2I april 2004; Rvs, afdeling bestuursrechtspraak, arrest nr. I82454 van 28 april 2008.

I54 Voor de meest recente zaken zie Grondwettelijk Hof, arrest nr. 29/2010, I8 maart 2010, B32-B34; Grondwettelijk Hof, nr. 99/20I0, I6 september 20I0; Grondwettelijk Hof, nr. I/20II, I3 januari 20II, B 6.5 en B. II.6.

I55 Grondwettelijk Hof, nr. 29/2010, I8 maart 2010, B32-B34.

I56 Het eHealth-platform is een openbare instelling die is opgericht om een beveiligde uitwisseling van persoonlijke gezondheidsgegevens tussen de actoren in de gezondheidszorg tot stand te brengen.

I57 Grondwettelijk Hof, nr. IIO/2005, 22 juni 2005: het recht op arbeid en billijke beloning houdt niet in dat arbeid die wordt verricht in het kader van een opleiding zonder dat daarbij een doelstelling in termen van economische productiviteit wordt opgelegd, moet worden vergoed.

I58 Grondwettelijk Hof, arrest nr. 99/2008, 3 juli 2008.

I59 Grondwettelijk Hof, arrest nr. 9/2009 van I5 januari 2009, B53 (uit artikel 23, derde lid, $I^{\circ}$ van de Grondwet kan niet worden afgeleid dat de wetgever aan elke werknemer het voormelde recht dient te waarborgen door hem persoonlijk toegang te verschaffen tot de overlegorganen die hij instelt en waarvan hij de samenstelling en de verkiezing regelt. In zoverre de wetgever de toegang tot die organen heeft geregeld door een zekere mate van representativiteit van de werknemersorganisaties te vereisen, zijn de bepalingen niet zonder verantwoording).

I6o Zie ook bijvoorbeeld Grondwettelijk Hof, nr. 70/99, I7 juni I999; Grondwettelijk Hof, nr. 28/2002, 30 januari 2002.

I6I Grondwettelijk Hof, nr. 99/2008, 3 juli 2008 (de keuze van de decreetgever om geen nieuwe milieuvergunningen uit te reiken en bijgevolg geen nieuwe veeteeltinrichtingen toe te laten, is niet zonder redelijke verantwoording). 
het arrest Coomans dat artikel 4, $4^{\circ}$ van het Europees Sociaal Handvest met betrekking tot het recht op redelijke opzeggingstermijnen 'voldoende precies is om directe werking te hebben in de interne rechtsorde in zoverre aan de staten een verbod tot het nemen van bepaalde maatregelen wordt opgelegd'. ${ }^{\text {.62 }}$ De Raad besluit dat een termijn van tien dagen ten aanzien van een persoon die op het ogenblik van de afdanking wegens beroepsongeschiktheid al sedert meer dan 25 jaar in dienst is van de overheid, niet als een redelijke opzeggingstermijn kan worden beschouwd. Over de vraag of en in welke mate artikel $4,4^{\circ} \mathrm{ESH}$ ook directe werking heeft in zoverre het aan de staten de verplichting oplegt om bepaalde beschermende maatregelen te nemen, spreekt de Raad zich niet uit. Dat was immers in de voorliggende zaak 'niet aan de orde' want 'de verzoeker klaagt niet over het uitblijven van een door de overheid te nemen maatregel of over een ontoereikende maatregel, maar over het feit dat de overheid te zijnen opzichte een beperkende maatregel heeft genomen'. De Raad van State maakt dus - net als in Coomans - het onderscheid tussen negatieve en positieve verplichtingen en voert aan dat de negatieve verplichting voldoende duidelijk bepaald kunnen worden.

34. De geciteerde rechtspraak toont aan dat wel degelijk getoetst wordt aan het recht op arbeid. Het lijkt evenwel moeilijk om op basis van die rechtspraak in abstracto weer te geven wat dat recht precies inhoudt. De rechters gaan liever in concreto over tot een proportionaliteitstoets om na te gaan of een bepaalde maatregel niet kennelijk onredelijk is, rekening houdend met de sociale en economische context. ${ }^{16_{3}}$ Artikel 23 van de Grondwet biedt in elk geval volgens de rechtspraak soms bescherming, al is het op basis van die rechtspraak nog niet helemaal duidelijk of die bescherming beperkt is tot negatieve verplichtingen of ook positieve verplichtingen inhoudt.

\section{Recht op sociale zekerheid}

35. Artikel 23 , derde lid $2^{\circ}$ benoemt als een van de relevante sociale rechten het recht op sociale zekerheid, bescherming van de gezondheid en sociale, geneeskundige en juridische bijstand. Op het eerste gezicht lijkt men voor dit recht meestal een beroep te doen op het standstill-beginsel. ${ }^{164}$ Toch zou men kunnen argumenteren dat ook dit recht soms een rechtstreekse bescherming biedt. Zo veroordeelt het Grondwettelijk Hof het afschaffen van de maatschappelijke dienstverlening voor de vreemdeling die om medische redenen in de absolute onmogelijkheid verkeert om gevolg te geven aan het bevel om het land te verlaten. ${ }^{165}$ Het Grondwettelijk Hof stelt, na te wijzen op het recht van de betrokken vreemdeling om een menswaardig leven te leiden,

I62 Rvs, afdeling bestuursrechtspraak, arrest nr. I82454 van 28 april 2008. Vgl. Rvs, afdeling bestuursrechtspraak, nr. 86787 van I4 april 2000 en Rvs, afdeling bestuursrechtspraak, arrest nr. I65I 26 van 27 november 2006 waarin gesteld wordt dat artikel I van het ESH (recht op arbeid) geen directe werking heeft.

I63 Zie Grondwettelijk Hof, nr. 5/2004, I4 januari 2004 waarin erkend wordt dat de verwezenlijking van het recht op arbeid voor ieder af hankelijk is van economische factoren die de Belgische wetgevers niet volledig beheersen.

I64 Grondwettelijk Hof, nr. I35/20II, 27 juli 201 .

I65 Grondwettelijk Hof, nr. 80/99, 30 juni I999. Bevestigd door Grondwettelijk Hof, nr. I35/20II, 27 juli 20II, B. I5.II. 
dat het afschaffen van de maatschappelijke dienstverlening voor personen die zich in fundamenteel verschillende situaties bevinden (diegenen die kunnen worden verwijderd en diegenen die om medische redenen niet kunnen worden verwijderd) een schending uitmaakt van het gelijkheidsbeginsel omdat het verschillende categorieën op dezelfde wijze behandelt zonder redelijke verantwoording. In een recent arrest van het Grondwettelijk Hof was de vraag aan de orde of de mogelijkheid voor FEDASIL om door middel van een individuele gemotiveerde beslissing vanaf de derde asielaanvraag het recht op materiële opvang te beperken een schending uitmaakt van artikel 23 van de Grondwet. Hoewel het Grondwettelijk Hof de vraag via de lens van het standstill-beginsel analyseert en concludeert dat er geen sprake is van een aanzienlijke achteruitgang, ${ }^{166}$ is het vooral de evenredigheidstoets die opvalt. Het Grondwettelijk Hof stelt dat de maatregel pertinent en niet onevenredig is. Wat daarbij in het oog springt, is de nadruk op de plichten van het individu, vanuit het idee dat de burger dient mee te werken aan de sociale en economische vooruitgang van de maatschappij waarin hij leeft. Om toegang te verkrijgen tot de sociale en economische rechten, kunnen volgens het Grondwettelijk Hof verplichtingen worden opgelegd. Die verplichtingen moeten de personen aan wie zij worden opgelegd, in staat stellen bij te dragen tot de effectieve verwezenlijking van een menswaardig leven voor eenieder, en moeten evenredig zijn met de aldus bepaalde doelstelling. ${ }^{167}$ Artikel 23 van de Grondwet kon dus niet zo gelezen worden dat het een bestraffing of maatregel tegen eventueel misbruik van het recht op maatschappelijke dienstverlening zou verhinderen. Het is een legitieme doelstelling om een 'carrouselmechanisme' te willen doorbreken waarbij opeenvolgende asielaanvragen worden ingediend met de enkele bedoeling het verblijf in een opvangcentrum te verlengen. Ook de wetgeving die in een maximale tijdelijke schorsing van één maand van de materiële opvang voorziet bij een zeer ernstige inbreuk op het huishoudelijk reglement van de opvangstructuur werd als niet-onevenredig beschouwd. ${ }^{168} \mathrm{Bij}$ deze vaststellingen komt de verwijzing naar de standstill enigszins artificieel over: men gaat vooral de evenredigheid van de maatregel of de sanctie na in het licht van de door de wetgever nagestreefde doelstelling. De vraag of het beschermingsniveau inzake maatschappelijke dienstverlening aanzienlijk is verminderd, is daarbij eigenlijk van ondergeschikt belang.

\section{Nog veel onzekerheid}

36. In bepaalde arresten van het Grondwettelijk Hof en de Raad van State kan men aldus een tendens ontwaren waarbij rechtstreeks getoetst wordt aan sociale en economische rechten. Deze benadering, die doet denken aan de rechtspraak van

I66 Grondwettelijk Hof, nr. I35/20II, 27 juli 20II, B.9.5.

I67 Grondwettelijk Hof, nr. I35/20II, 27 juli 20II, B.9.5. Zie ook B. 19.I

I68 Grondwettelijk Hof, nr. I35/20II, 27 juli 20II, B. I9.3. De betrokken vreemdeling behoudt met name het recht op medische begeleiding. Bovendien staat een beroep met volle rechtsmacht open. De sanctie is beperkt tot situaties waarbij het personeel of de andere bewoners van de opvangstructuur in gevaar worden gebracht of die duidelijke risico's inhouden voor de veiligheid of de naleving van de openbare orde in de opvangstructuur. 
buitenlandse Grondwettelijke Hoven, ${ }^{169}$ staat evenwel nog in haar kinderschoenen. Beide Belgische rechtscolleges verpakken hun benadering vaak nog anders door een beroep te doen op de standstill of andere grondrechten, het aantal vastgestelde schendingen is beperkt en tot op vandaag wordt nog in sommige arresten geargumenteerd dat de sociale en economische bepalingen onvoldoende precies zijn om aan te kunnen toetsen. De rechtstreekse toetsing in objectieve contentieux vereist vooral dat de precieze betekenis van die sociale en economische grondrechten verduidelijkt wordt. Volgens de tegenstanders van een rechtstreekse toetsing is net dit onmogelijk. Om vast te stellen wat de bescherming van die grondrechten inhoudt, kan evenwel een beroep worden gedaan op de groeiende (quasi-) rechtspraak van internationale organen. Zo identificeert het Comité bij het IVESCR de harde kern van ieder recht. Eerst gebeurde dit op een abstracte wijze, maar vanaf de algemene opmerking nr. I3 overloopt het Comité op een pragmatische wijze de verplichtingen met het oog op het garanderen van het minimumniveau. ${ }^{170}$ Er kan ook verwezen worden naar de aanbevelingen van de Internationale Arbeidsorganisatie, het werk van de European Union Agency for Fundamental Rights (FRA) en de quasi-rechtspraak van het Europees Comité voor sociale rechten. Aangezien sociale en economische grondrechten afhankelijk zijn van de economische en sociale context, lijkt het vooral interessant om even kort stil te staan bij de conclusies en rechtspraak van het ESH-Comité (infra nr. 38). Alvorens dit te doen, is het evenwel belangrijk om erop te wijzen dat de vaststelling dat rechtstreeks getoetst kan worden ook repercussies heeft voor het subjectief contentieux, althans voor zover men aanneemt dat de subjectieve voorwaarde voor de rechtstreekse werking geen belang meer heeft (zie supra nr 23).

\section{Directe werking in subjectief contentieux}

37. In de gevallen waarbij de precieze betekenis van sociale en economische grondrechten kan worden vastgesteld op basis van de nationale en internationale rechtspraak of rapporten, lijkt het niet langer onmogelijk voor de nationale rechter om rechtstreeks te toetsen aan deze grondrechten. Vanderlinden stelt zelfs dat 'het principe van de harde kern probleemloos zal kunnen worden toegepast voor de Belgische hoven en rechtbanken. ${ }^{, 77 \mathrm{I}}$ De rechtszoekende zal kunnen rekenen op een minimale rechtsbescherming van sociale en economische grondrechten. Dit zal in eerste instantie een bescherming tegen overheidshandelen inhouden (waarbij bestaande rechten dreigen te worden aangetast), maar er kan a priori niet uitgeslo-

I69 Zo kan verwezen worden naar het Zuid-Afrikaans Grondwettelijk Hof in de Grootboom-zaak van 4 oktober 2000. Daar ging het om de bezetting van openbare eigendommen door straatarme krotbewoners. Het Zuid-Afrikaans Grondwettelijk Hof stelde daar vast dat de overheid was tekortgeschoten in de verplichting om het recht op behoorlijke huisvesting te beschermen.

I70 H. Vanderlinden, 'Effectiviteit van de sociale grondrechten in het Belgische recht, mythe of realiteit?', RW 2008-2009, I207; O. De Schutter, 'Le protocole faculatatif au pacte international relatif aux droits économiques, sociaux et culturels?’, R.B.D.I. 2006, 29 en 30.

I7I H. Vanderlinden, 'Effectiviteit van de sociale grondrechten in het Belgische recht, mythe of realiteit?', RW 2008-2009, I208. 
ten worden dat sociale grondrechten ook bepaalde minimumverplichtingen om iets te doen opleggen aan de Staat. In principe is het aan de wetgever om de sociale en economische rechten te waarborgen, maar daarbij moet een bepaalde minimumbescherming gerespecteerd zijn. Dat het evenwel niet altijd een eenvoudige zaak is om de draagwijdte van de bescherming te ontwaren, kan geïllustreerd worden met de (minderheids)rechtspraak die het recht op huisvesting als een subjectief recht beschouwt. ${ }^{172}$

Zo erkende de kortgedingrechter in Brussel dat 'het recht op een behoorlijke huisvesting een subjectief recht is, inroepbaar ten aanzien van OCMW's.' ${ }^{\text {173 }}$ Het betrof een zaak waarbij een gezin met vijf kinderen tijdelijk logeerde in lokalen van het OCMW. De relatie met het OCMW was evenwel gespannen en na verloop van tijd wilde het OMW die mensen buiten. De rechter stelde dat het subjectief recht op huisvesting verhindert dat een vraag tot uitzetting ingewilligd zou worden zonder dat het OCM een alternatief formuleert. ${ }^{174}$ De erkenning van het subjectief recht betekende evenwel niet dat de hulp van het OCMW onvoorwaardelijk moest zijn. De betrokkenen moesten naar alternatieven helpen zoeken en het OCMW (dat geen eigenaar was van sociale woningen) beschikte niet over de middelen om zelf de mensen te huisvesten. Dit voorbeeld illustreert treffend hoe de toetsing aan sociale rechten niet noodzakelijk betekent dat geen belangenafweging zal gemaakt moeten worden, wel integendeel. Men kan door zijn gedrag verzaken aan het recht op de uitoefening van het grondrecht. De plichten van het individu worden afgewogen tegen de plichten van de staat (in casu het OCMW). En in dit geval oordeelde de rechter dat gelet op de wettelijke taken en de middelen van het OCMW deze laatste moest helpen zoeken naar een oplossing maar onmogelijk zelf voor huisvesting kon zorgen. Ook de vrederechter in Ukkel oordeelde in dezelfde zin. ${ }^{175}$

I72 Ook andere sociale rechten werden reeds door de rechtspraak als subjectieve rechten beschouwd. Zo kent het Hof van Beroep van Brussel het recht op gezondheid rechtstreekse werking toe (Hof van Beroep Brussel van Io juni 2003 aangehaald in Rvs, afdeling bestuursrechtspraak, arrest nr. I54.2I7 van 27 januari 2006). Voor een overzicht van rechtspraak zie H. Funck, 'L'article 23 de la constitution à travers la jurisprudence des cours et tribunaux (1994-2008): un droit en arrièrefond ou l'ultime recours du juge?', in: W. Rauws en M. Stroobant (ed.), Sociale en economische grondrechten, Antwerpen/Louvain-la-Neuve, Intersentia/Anthemis, 69-III.

I73 Kort. Ged. Rb. Brussel, I9 juni 2002, JT 2002, 50; Echos du logement, 2004, 27 : 'que la doctrine et la jurisprudence reconnaissent que le droit au logement décent constitue un droit subjectif, particulièrement à l'égard des instituions chargées de l'aide sociale.'

I74 In dezelfde zin neemt de rechtspraak van de Raad van State aan dat er sprake is van een moeilijk te herstellen nadeel wanneer iemand uit zijn woning wordt gezet zonder dat de overheid heeft helpen zoeken naar een alternatieve huisvesting, terwijl de personen in kwestie niet over voldoende middelen beschikken. Rvs, I2 februari 2003, Leroy et Postiaux, nr. II5/808 : 'le droit à un logement décent est garanti par l'article 23 de la Consitution (), qu'il ne ressort d'aucun élément transmis au Conseil d'Etat que le bourgmestre se soit soucié, avant de prendre la mesure litigieuse, d'aider les occupantes à retrouver un logement, ni même qu'il se serait soucié des possibilités concrètes que celles-ci avaient de retrouver un logement décent en remplacement de ce qu'il considère comme un taudis; () que de surcroit, les requérants signalent disposer de ressources modestes et affirment, sans êtres contredites, ne pas avoir les moyens nécessaires pour, à la fois, faire face aux frais de relogement et avancer les fonds requis pour procéder à des travaux d'assainissement.'

I75 Vred. Ukkel, I6 april 2007, JLMB 2007, I003: 'le droit au logement, consacré par l'article 23 de la Constitution et 3 de Code du Logement, implique qu'un juge ne puisse faire droit à une demande d'expulsion d'un locataire qui se maintient sans titre, ni droit dans un immeuble, après que le bail ait pris fin, sans enjoindre aux pouvoirs publics de le reloger préalablement.' 
Er is evenwel rechtspraak die nog een stap verder gaat. Zo oordeelden andere rechters dat niets het OCMW belet om financiële steun te bieden. Ook de Belgische kinderen van een illegaal in België verblijvende moeder hebben recht op huisvesting. Om te vermijden dat ze op straat zouden belanden, dient het OCMW de helft van de lopende huur te betalen. ${ }^{176}$ En men zou ook kunnen verwijzen naar de Brusselse arbeidsrechtbank die FEDASIL veroordeelt om asielaanvragers te herbergen, op straffe van een dwangsom. . $^{177}$

Voor al deze rechters vloeit uit het recht op menswaardig leven van artikel 23 van de Grondwet wel degelijk een rechtstreekse verplichting voor de overheid ${ }^{178}$ om inspanningen te leveren wanneer zwakkere bevolkingsgroepen zonder huisvesting dreigen te vallen. Het recht op een menswaardig leven is immers in artikel 23 van de Grondwet geformuleerd als een recht; alleen de draagwijdte ervan is nog niet voldoende duidelijk en leidt tot verschillende conclusies. Voor huisvesting zou men op het eerste gezicht kunnen argumenteren dat dit niet zo'n groot probleem is: de meesten zullen het eens zijn dat in onze maatschappij een menswaardig leven pas mogelijk is als men ergens kan slapen en leven. Dit betekent evenwel niet dat men altijd het recht kan claimen. Het individu heeft ook plichten en zal die moeten vervullen om zijn aanspraken hard te maken. Dit zal in concreto moeten nagegaan worden door de rechter. Bovendien illustreren deze voorbeelden dat het niet altijd evident is om de concrete verplichting voor de Staat vast te leggen: er is een hemelsbreed (financieel) verschil tussen de verplichting om te helpen zoeken naar huisvesting en de verplichting om financiële steun te bieden. In principe is het aan de wetgever om hierover te oordelen. De rechter kan pas na een zorgvuldige afweging van de belangen en rekening houdend met de plichten van het individu optreden voor zover de wetgeving en praktijk onvoldoende is om te garanderen dat de sociale beschermingsdrempel om een menswaardig leven te bereikt is.

\section{Collectief klachtrecht en rapportering voor het Europees Comité voor sociale rechten (ESH-Comité)}

38. De meerwaarde van de opname van sociale en economische rechten in een internationaal verdrag ligt er vooral in dat het een internationale controle toelaat op de nationale wetgeving en praktijk en dat controleorganen de draagwijdte van de verplichtingen kunnen helpen verduidelijken. Op Europees niveau kan gewezen worden op het bestaan van het ESH-Comité, een quasi-rechterlijke instantie bestaande uit I5 onafhankelijke en onpartijdige experts, dat bevoegd is om via gezaghebbende

I76 Arbrb. Brussel, 2I februari 2008, Chr. D.S.-Soc. Kron. 2010, 77-78.

177 Weliswaar met verwijzing naar artikel 3 EVRM en de nationale wetgeving (en niet naar artikel 23 van de Grondwet). Arbrb. Brussel, 23 september 2009, T. Vreemd. 20I0, 40.

I78 Of artikel 23 van de Grondwet ook verplichtingen oplegt aan de private verhuurder is nog controversiëler. Het vredegerecht van Brussel (vierde kanton) is alvast van oordeel dat het ook rechtstreekse werking heeft ten aanzien van een immobiliënvennootschap met een sociaal doel (Vredegerecht Brussel (vierde kanton), 26 mei 2009, TBBR 2009, 508-509). Zie ook J. Sohier, 'La cour constitutionnelle, juge de la conciliation des droits fondamentaux: le droit de propriété face au droit au logement', in: Liège, Strasbourg, Bruxelles: parcours des droits de l'homme. Liber amicorum Michel Melchior, 20I0, Anthemis, 205-206. 
juridische beslissingen het (herziene) ESH te interpreteren en toe te passen. Dit gebeurt op twee manieren: ten eerste moeten staten periodiek rapporteren over de naleving van het verdrag en het comité evalueert dan de toestand door 'conclusies' goed te keuren, ${ }^{179}$ ten tweede kunnen collectieve klachten ingediend worden door bepaalde organisaties, zoals vakbonden, werkgeversorganisaties, en NGO's. ${ }^{180}$ België heeft deze collectieve klachtenprocedure aanvaard ${ }^{18 \mathrm{I}}$ en een beperkt aantal zaken zijn tegen België gewezen ${ }^{182}$ of nog hangend, ${ }^{183}$ waarbij het recent verschillende schendingen van de rechten van woonwagenbewoners heeft vastgesteld. ${ }^{184}$ Het voordeel van dit systeem is dat men geen nationale rechtsmiddelen moet uitputten en dat ook preventief een bepaalde praktijk of wet aangeklaagd kan worden. ${ }^{185}$ De klagers moeten niet zelf het slachtoffer zijn. Dit klachtenmechanisme kan ervoor zorgen dat het ESH-Comité de draagwijdte van sociale en economische rechten beter kan toelichten. ${ }^{186}$ Een toonaangevende zaak was FENSEA t. Frankrijk. ${ }^{187}$ In deze zaak wordt erop gewezen dat sociale en economische rechten, geen louter theoretische, maar concrete en effectieve rechten zijn. Staten moeten onder meer alle middelen inzetten om de doelstellingen te verwezenlijken, betrouwbare statistieken bijhouden om

I79 De laatste conclusies ten aanzien van België hadden betrekking op 'Health, social security and social protection' (2009), 'Labour rights' (2010) en 'Children, Family and Migrants' (20II).

I8o R. Brillat, 'De collectieve klachtenprocedure van het Europees Sociale Handvest en de strijd tegen armoede', in: Steunpunt tot bestrijding van armoede, bestaansonzekerheid en sociale uitsluiting (ed.), 10 jaar samenwerkingsakkoord, 2008, 74-80 (<www.armoedebestrijding.be/publicat ions/rojaarsamenwerking/rojaarsamenwerking_rapport_NL.pdf $>$ ). Slechts een beperkt aantal NGO's is bevoegd om een klacht in te dienen: concreet mogen 7I van de 400 internationale NGO's die bij de werking van de Raad van Europa zijn betrokken, een klacht indienen. België heeft nog niet aanvaard dat nationale NGO's klachten kunnen indienen.

I8I België heeft het Protocol bij het Handvest op 23 juni 2003 aanvaard (supra).

I82 ESH-Comité, World Organisation against Torture (OMCT) t. België, nr. 2I/2003 van 26 januari 2005 (i.v.m. lijfelijke bestraffing van kinderen); ESH-Comité, Centrale générale des services publics t. België, nr. 25/2004 van 27 mei 2005 (i.v.m. het recht op collectief onderhandelen); ESH-Comité, European Trade Union Confederation (ETUC)/ Centrale Générale des Syndicats Libéraux de Belgique (CGSLB)| Confédération des Syndicats chrétiens de Belgique (CSC)/ Fédération Générale du Travail de Belgique (FGTB) t. België, nr. 59/2009 van I6 september 201 I (i.v.m. het recht op staken); ESH-Comité, International Federation of Human Rights Leagues (FIDH) t. Belgium, nr. 62/20Io van 2I maart 2010 (i.v.m. de huisvesting van Roma-zigeuners). <www.coe.int/t/dghl/monitoring/socialcharter/Complaints/ Complaints_en.asp>.

I83 ESH-Comité, International Federation of Human Rights (FIDH) t. België, nr.75/20II (i.v.m. de situatie van bijzonder afhankelijke mindervalide volwassenen).

I84 Het ESH-Comité stelde schendingen vast van artikel I6 en $30 \mathrm{ESH}$, telkens in combinatie met het gelijkheidsbeginsel. ESH-Comité, International Federation of Human Rights Leagues (FIDH) t. België, nr. 62/20Io van 2I maart 2010 (i.v.m. de huisvesting van Roma-zigeuners). <www.coe.int/t/dghl/ monitoring/socialcharter/Complaints/Complaints_en.asp >.

I85 R. Brillat, 'De collectieve klachtenprocedure van het Europees Sociale Handvest en de strijd tegen armoede', in: Steunpunt tot bestrijding van armoede, bestaansonzekerheid en sociale uitsluiting (ed.), 10 jaar samenwerkingsakkoord, 2008, 76-77 (<www.armoedebestrijding.be/publicati ons/rojaarsamenwerking/rojaarsamenwerking_rapport_NL.pdf $>$ ).

I86 Voor een overzicht van de beslissingen van het ESH-Comité, zie CoE, Digest of the Case Law of the Committee of Social Rights, I September 2008, <www.coe.int>.

I87 N. Bernard, 'Le droit au logement dans la charte sociale révisée: à propos de la condamnation de la France par le comité européen des droits sociaux', Rev. trim.dr.h. 2009, Io62-Io89; M. Uhry en T. Viard, 'De Raad van Europa pakt Frankrijk aan over het recht op huisvesting en het recht op bescherming tegen armoede', in: Steunpunt tot bestrijding van armoede, bestaansonzekerheid en sociale uitsluiting (ed.), 10 jaar samenwerkingsakkoord, 2008, 74-80 (<www.armoedebestrijding.be/publications/rojaarsamenwerking/rojaarsamenwerking_rapport_NL.pdf >), 8I-88. 
resultaten en middelen te vergelijken, stappenplannen uitwerken, oog hebben voor de impact van keuze voor de meest kwetsbaren, als de verwezenlijking van het recht ingewikkeld en duur is alles in het werk stellen om het doel binnen een redelijke termijn te verwezenlijken, ervoor zorgen dat de vooruitgang meetbaar is. Het ESHComité oordeelde in deze zaak dat artikel 3I ESH geschonden was, ${ }^{188}$ onder meer omdat er onvoldoende vooruitgang was geboekt in de strijd tegen mensonwaardige omstandigheden, er onvoldoende sociale woningen voor de armsten toegankelijk waren en het opvangbeleid voor woonwagenbewoners onvoldoende was. Vooral de nadruk op concrete en effectieve rechten is interessant. In die context zou men bijvoorbeeld kunnen opperen dat de Staat er nu ook voor moet zorgen dat artikel I34bis Nieuwe Gemeentewet en artikel go van de Vlaamse Wooncode ook in de praktijk worden toegepast. Het is immers een publiek geheim dat het zogenoemde sociale beheersrecht op leegstaande gebouwen in de praktijk om verschillende redenen weinig tot geen succes kent. Ook de wetgeving inzake affichage van huurprijzen van woningen wordt niet of amper nageleefd. Het ESH-Comité is daar om eraan te herinneren dat de wetgeving ook in de praktijk moet worden toegepast. Wetgeving moet ook effectief zijn. Het nadeel blijft evenwel dat het ESH-Comité geen juridisch bindende beslissingen kan nemen. Als slachtoffer hebt u bovendien ook geen individueel klachtrecht. Uiteraard kan het slachtoffer wel voor de nationale rechtbanken pogen te argumenteren dat het ESH (of sommige onderdelen ervan) rechtstreekse werking hebben. Men zal echter snel in dezelfde discussie belanden als voor artikel 23 van de Grondwet: de meeste rechters nemen aan dat het ESH geen subjectieve rechten toekent. Een alternatief is om met de uitspraak van het ESH-Comité in de hand bij de nationale rechter schadevergoeding te claimen voor de nalatigheid van de wetgever of de uitvoerende macht. De recente rechtspraak van het Hof van Cassatie met betrekking tot de aansprakelijkheid van de wetgever opent op dat vlak misschien nieuwe deuren. ${ }^{189}$

\section{Rechtstreeks afdwingen voor het Hof van Justitie?}

39. Dit artikel focust hoofdzakelijk op de nationale rechtswaarborgen voor een herijking van de sociale welvaartsstaat. Toch dient even stilgestaan te worden bij de vraag of het Hof van Justitie meer of minder rechtswaarborgen biedt dan de nationale regelgeving en rechters. Deze vraag lijkt aan belang te zullen winnen aangezien de Europese Unie steeds meer aandacht heeft voor de sociale en economische politiek van de lidstaten. De vraag is niet eenvoudig te beantwoorden. Wel staat het vast dat het Handvest van de Grondrechten expliciet en uitvoerig melding maakt van de sociale en economische grondrechten. Momenteel heerst evenwel een breed debat over de precieze juridische betekenis van deze grondrechten. De betekenis

I88 Hoewel België artikel 3I ESH niet erkend heeft, kan een beroep worden gedaan op artikel I6 en 30 om het recht op huisvesting van bepaalde kwetsbare categorieën te beschermen. Zie ESHComité, International Federation of Human Rights Leagues (FIDH) t. België, nr. 62/20Io van 2I maart 2010 (i.v.m. de huisvesting van Roma-zigeuners).

I89 Hof van Cassatie, 28 september 2006, (Belgische Staat/F.J.M.L), RW 2006-07, 27. 
van het in het Handvest gemaakte onderscheid tussen rechten en principes is voorlopig nog niet helemaal duidelijk en het is koffiedik kijken in welke richting de rechtspraak van het Hof van Justitie zal evolueren. Wel kan voorlopig vastgesteld worden dat het Hof nauwlettend toekijkt op de naleving van de (weinige) Europeesrechtelijke sociale regelgeving. ${ }^{190}$ De opbouw van het Handvest, met in het eerste artikel de nadruk op de menselijke waardigheid, maakt in elk geval duidelijk dat een menswaardig leven alleen mogelijk is als zowel burgerlijke en politieke als sociale en economische grondrechten gerespecteerd zijn. Of zoals president Roosevelt ooit terecht opmerkte: 'freedom from want ${ }^{\text {'19r }}$ is een essentiële vrijheid voor eenieder die op deze aardbol rondloopt.

\section{Tussenbesluit}

40. De sociale en economische grondrechten zijn niet de enige rechtswaarborgen bij een herijking van de sociale welvaartsstaat. In eerste instantie zou men geneigd kunnen zijn om enkel naar die grondrechten terug te grijpen om te begrijpen welke de grenzen zijn die gerespecteerd moeten worden. Deze benadering is evenwel onvolledig.

Het grootste nadeel van een beroep op sociale en economische grondrechten lijkt de heersende onduidelijkheid over hun draagwijdte waardoor er ook verwarring heerst tussen de taken van de wetgever en de rechter. Men kan argumenteren dat het, net als bij burgerlijke en politieke rechten, slechts een kwestie van tijd is vooral de inhoudelijke betekenis van sociale grondrechten vastgelegd zal worden via nationale en internationale rechtspraak. De wetgever zal dan zowel in het objectief als het subjectief contentieux teruggefloten kunnen worden door de rechter als hij aan die (harde kern van de) beschermde rechten raakt door op te treden of net niet op te treden zonder dat er daarvoor een gerechtvaardigde verantwoording is of, om de gekende woorden van het EVRM te gebruiken, zonder dat daarvoor een noodzaak is in een democratische samenleving. Er zijn zoals hierboven aangetoond sterke aanwijzingen, maar dit is geen welomlijnde en vaststaande tendens, dat de rechtspraak in die zin evolueert. Anderzijds wordt ook vaak gezegd dat sommige sociale en economische grondrechten een programmatorisch karakter hebben. In die visie wordt de harde kern van de sociale grondrechten slechts als een vertrekpunt naar ruimere rechtsbescherming gezien. ${ }^{192}$ Het volstaat dan niet langer om zich af te vragen of de minimale sociale rechten van het individu voldoende beschermd zijn rekening houdend met het proportionaliteitsbeginsel, maar men zal zich ook

I9o Zie bijvoorbeeld het arrest over ziekte tijdens het jaarlijks verlof (HvJ C-282/Io, Dominguez v. Centre informatique du Centre Ouest Atlantique, 24 januari 20I2).

I9I De 'Four Freedoms' zijn: freedom of speech and expression, freedom of worship, freedom from want and freedom from fear. Deze zijn terug te vinden in de Preambule van de UVRM: 'Whereas disregard and contempt for human rights have resulted in barbarous acts which have outraged the conscience of mankind, and the advent of a world in which human beings shall enjoy freedom of speech and belief and freedom from fear and want has been proclaimed the highest aspiration of the common people,....'

I92 H. Vanderlinden, 'Effectiviteit van de sociale grondrechten in het Belgische recht, mythe of realiteit?', RW 2008-2009, I208. 
moeten afvragen of de wetgever terug kan komen op bepaalde verworven sociale rechten (cf. het standstill-beginsel) en voldoende meetbare vooruitgang boekt. De praktijk van het Grondwettelijk Hof en de Raad van State (zowel afdeling wetgeving als afdeling bestuursrechtspraak) toont aan dat de verwijzing naar de standstill in essentie neerkomt op een afweging van belangen, waarbij de rechters niet snel tot een schending besluiten. De standstill is dan ook slechts een bijzondere uitdrukkingsvorm van de positieve verplichting. De cruciale vraag lijkt daarom voor alle grondrechten steeds dezelfde te moeten zijn: zijn de fundamentele rechten van het individu, gelet op zijn eigen plichten en de middelen waarover de Staat beschikt, voldoende gewaarborgd opdat hij een menswaardig leven zou kunnen leiden. De wetgever moet de grondrechten in principe waarborgen, maar als hij daarbij faalt, moet de rechter hem daarop kunnen wijzen. Bij sociale en economische grondrechten dient men doorgaans gelet op het meer politieke en complexe karakter van de te maken keuzes evenwel te onthouden dat de appreciatiemarge voor de wetgever groter dient te zijn, en dus het optreden van de rechter met (nog meer) omzichtigheid dient te gebeuren dan bij burgerlijke en politieke rechten. Het Grondwettelijk Hof benadrukt dit door enkel het kennelijk onredelijk optreden van de wetgever te sanctioneren, behalve wanneer een bijzonder kwetsbare groep benadeeld dreigt te worden. Dan is de appreciatiemarge beperkter.

De exclusieve nadruk op sociale en economische grondrechten zou ook tot een onvolledige analyse leiden. Zoals we in het volgende deel zullen zien, biedt het EVRM eveneens rechtsbescherming bij een herijking van de sociale welvaartsstaat. Dit heeft op het eerste gezicht het voordeel dat de discussies over de rechtstreekse werking achterwege zullen blijven. Daarnaast is er ook geen discussie over het bindende karakter van de rechtspraak van het Europees Hof voor de Rechten van de Mens.

\section{De 'omweg' via het EVRM}

4I. Het EHRM heeft reeds in I979 in Airey t. Ierland benadrukt dat er geen ondoordringbare afscheiding bestaat tussen economische en sociale rechten en burgerlijke en politieke rechten. ${ }^{193}$ Hoewel het EVRM in essentie burgerlijke en politieke rechten vastlegt, hebben vele van die burgerlijke en politieke rechten sociale of economische implicaties. ${ }^{194}$ Sindsdien heeft het EHRM er bovendien steeds op gehamerd dat het overeenkomstig artikel 3I van het Weens Verdrag over het Verdragenrecht bij de interpretatie van het EVRM rekening dient te houden met alle relevante internationale regels, waaronder dus ook de verdragen inzake sociale en economische

I93 EHRM, Airey t. Ierland, arrest van 9 oktober 1979 , Serie A, nr. 32, § 26: 'The mere fact that an interpretation of the Convention may extend into the sphere of social and economic rights should not be a decisive factor against such an interpretation; there is no water-tight division separating that sphere from the field of the convention.'

I94 EHRM, Airey t. Ierland, arrest van 9 oktober 1979, Serie A, nr. 32: [While the Convention] sets forth what are essentially civil and political rights, many of them have implications of social or economic nature.' 
grondrechten. Zo verwees het EHRM veelvuldig naar ILO-verdragen ${ }^{195}$ of het $\mathrm{ESH}^{196}$ om het EVRM te interpreteren. In 2008 heeft de Grote Kamer van het EHRM in Demir en Baykara t. Turkije aangegeven dat de verwerende lidstaat deze verdragen niet noodzakelijk geratificeerd moet hebben, wat telt is de algemene overtuiging of opinio juris over hoe het EVRM geïnterpreteerd moet worden. ${ }^{197}$ Hoewel Turkije het ESH niet had geratificeerd, besloot het EHRM in die zaak dat er 'een waarneembare evolutie was in het internationaal recht en de nationale rechtssystemen' die een omkeer in zijn vaste rechtspraak rechtvaardigde. Artikel II EVRM was geschonden omdat gemeenteambtenaren het recht werd ontzegd om een vakbond op te richten en collectieve overeenkomsten te sluiten. ${ }^{198}$ Dit arrest onderstreept de groeiende aandacht van het EHRM voor de sociale en economische dimensie van burgerlijke en politieke rechten. ${ }^{199}$ Het EHRM lijkt dat zelf te willen benadrukken aangezien een van de factsheets op de website van het EHRM een overzicht geeft van de relevante rechtspraak van het EHRM over 'Social Welfare'. ${ }^{200}$ Het is dan ook belangrijk om deze evolutieve benadering van het EVRM door het EHRM kort te overlopen aan de hand van een aantal voorbeelden in de rechtspraak van datzelfde hof. ${ }^{201}$ Deze rechtspraak en benadering is immers ook geldig voor het Belgische niveau, hoewel sommige Belgische auteurs het EHRM op dat punt net sterk bekritiseren. ${ }^{202}$

42. Artikel 3 EVRM, dat folteringen, onmenselijke of vernederende behandelingen of straffen verbiedt, vormt een eerste belangrijke brug naar sociale en economische grondrechten. Zo erkent het EHRM in Pancenko t. Litouwen dat het EVRM geen sociale en economische rechten bevat, zoals een recht op arbeid, een recht op gratis

I95 Zie bijvoorbeeld EHRM, Van der Mussele t. België, arrest van 23 november I983, Serie A, nr. 70, § 32 (ILO 29 om dwangarbeid in de zin van artikel 4 te definiëren); EHRM, Sidabras en Džiautas t. Litouwen, arrest van 27 juli 2004, Reports 2004-VIII, \$ 47.

I96 Zie bijvoorbeeld EHRM, Sidabras en Džiautas t. Litouwen, arrest van 27 juli 2004, Reports 2004-VIII, § 47.

I97 EHRM, Grote Kamer, Demir en Baykara t. Turkije, arrest van I2 november 2008, Reports 2008, § 86: '[I]t is not necessary for the respondent State to have ratified the entire collection of instruments that are applicable in respect of the precise subject matter of the case concerned. It will be sufficient for the Court that the relevant international instruments denote a continuous evolution in the norms and principles applied in international law or in the domestic law of the majority of member States of the Council of Euorpe and show, in a precise area, that there is common ground in modern societies'. Zie ook F. Vanneste, 'Het Europees Verdrag voor de Rechten van de Mens: een bijzondere vorm van internationaal recht?', in: J.P. Loof en R.A. Lawson (ed.), 60 jaar Europees Verdrag voor de Rechten van de Mens - Een lichtend voorbeeld? Speciaal nummer NJCM-Bulletin 20I0, 713-7I4 en F. Vanneste, General International Law before Human Rights Courts: Assessing the Specialty Claims of Human Rights Law, Antwerp-Oxford, Intersentia, 2009, 213-348.

I98 EHRM, Grote Kamer, Demir en Baykara t. Turkije, arrest van 12 november 2008, Reports 2008.

I99 Sommige rechtsgeleerden argumenteren dat het EHRM een nieuwe geïntegreerde benadering van grondrechten voorstaat. Zie bijvoorbeeld V. Montouvalou, 'Work and Private Life: Sidabras and Dziautas v. Lithuania', ElRev. 2005, 573; C. Ovey, F. Jacobs en R. White, The European Convention on Human Rights, Oxford University Press, 2006 ( $4^{\text {th }}$. Ed), 573.

200 De factsheets binden weliswaar het EHRM niet, maar ze vormen mijn inziens toch een indicatie van wat er leeft binnen (de juridische diensten van) het EHRM.

201 Voor meer uitvoerige besprekingen zie onder meer F. Vlemminx, 'Het inlezen van economische, sociale en culturele rechten in het EVRM door het EHRM', NJCM-Buleltin: 6o jaar EVRM, 20I0, 8I3826 .

202 M. Bossuyt, 'De uitbreiding van de rechtsmacht van het Europees Hof van de Rechten van de Mens tot socialezekerheidsregelgeving: een rechterlijke revolutie?', R.W. 2007-08, 842-856. 
medische hulp of een recht om financiële hulp te eisen om een bepaalde levensstandaard te garanderen, maar het stelt wel dat de levensomstandigheden van een persoon binnen het toepassingsgebied van artikel 3 EVRM kunnen vallen. ${ }^{203}$ Ook het feit dat een pensioen of andere bijstand onvoldoende is, kan volgens het EHRM een probleem doen rijzen onder artikel 3 EVRM. ${ }^{204}$ In beide gevallen was echter de vereiste minimumgraad van ernst niet bereikt om een schending vast te stellen. Dat was wel het geval in de recentere Grote Kamer-zaak M.S.S. t. België en Griekenland (201I). ${ }^{205}$ Een asielzoeker werd op basis van de Dublin-II-Verordening door België uitgewezen naar Griekenland. In Griekenland kreeg hij een kaart van asielzoeker, zonder verdere opvang. Hij leefde letterlijk op straat en voerde aan dat hem nooit huisvesting werd aangeboden. In eerste instantie dekt het EHRM zich wat in. Artikel 3 (het verbod van onmenselijke of vernederende behandeling) houdt geen algemene verplichting in voor de lidstaten om iedereen van een woning te voorzien of om financiële hulp te geven om een bepaalde levensstandaard te bereiken. Vervolgens komt het echter tot een schending van artikel 3 omwille van de erbarmelijke levensomstandigheden van de betrokkene. Het EHRM wijst op de bijzonder kwetsbare positie van de asielzoeker, op de bijzonder ernstige situatie van extreme armoede en op de rapporten van de UNHCR waaruit blijkt dat er veel te weinig opvangplaatsen waren zodat de situatie niet aan de asielzoeker alleen kan liggen. Het gebrek aan actie van de overheid heeft tot een onmenselijke behandeling geleid. Het EHRM veroordeelt Griekenland (en ook België maar om andere redenen) tot een schadevergoeding en wijst op de noodzaak om algemene maatregelen te nemen om gelijkaardige schendingen in de toekomst te voorkomen. Dit arrest toont de enorme mogelijkheden aan om via artikel 3 EVRM de staat te wijzen op zijn positieve plicht om een menswaardig leven te garanderen voor eenieder onder zijn jurisdictie. Het vaststellen van een schending is evenwel een delicate evenwichtsoefening. Het EHRM probeert dan ook terecht de algemene draagwijdte in te perken: in casu gaat het om een kwetsbare groep, die zich in een bijzonder verwaarloosde situatie bevindt en deze situatie is niet de schuld van de eiser.

43. Ook artikel I van het Eerste Protocol, dat het recht op eigendom waarborgt, kan een brug vormen naar de sociale en economische rechten. Zo stelt het EHRM dat zowel contributieve als niet-contributieve sociale uitkeringen onder het recht op eigendom vallen. ${ }^{206}$ Wel kan de vraag rijzen of er sprake is van een 'legitieme verwachting om het effectief genot van een eigendomsrecht te verkrijgen'. ${ }^{207}$ Indien dat niet het geval is, biedt artikel I PI op zich geen bescherming (maar misschien

203 EHRM, Pancenko t. Litouwen, beslissing van 28 oktober 1999 , <www.echr.coe.int $>$.

204 EHRM, Larioshina t. Rusland, beslissing van 23 april 2002, <www.echr.coe.int>.

205 EHRM, Grote Kamer, M.S.S. t. België en Griekenland, arrest van 2I januari 20II, Reports 201 I.

206 EHRM, Grote Kamer, Stec e.a. t. Verenigd Koninkrijk, arrest van I2 april 2006, Reports 2006-VI. Zie ook EHRM, Gaygusuz t. Oostenrijk, arrest van I6 september 1996, Reports I996-IV en EHRM, Koua Poirrez t. Frankrijk, arrest van 30 september 2003 , Reports 2003-X.

207 Een niet-onherroepelijke uitspraak (van het Griekse Rekenhof) volstaat om met voldoende zekerheid de pensioenaanspraak van de verzoeker, een ambtenaar, vast te stellen. EHRM 2I maart 2002, Vasilopoulou t. Griekenland. 
wel in combinatie met artikel I4 EVRM). ${ }^{208}$ Het feit dat bepaalde sociale uitkeringen onder het toepassingsgebied van artikel I PI vallen is relevant wanneer sociale uitkeringen stopgezet worden of beperkt. ${ }^{209}$ In Kjartan Ásmundsson t. Ijsland van I2 oktober 2004 werd het pensioen voor mindervaliden van de eiser volledig stopgezet. Men had immers de berekeningswijze van iemands handicap gewijzigd om de financiering van het systeem te kunnen blijven garanderen. Het EHRM oordeelde dat de volledige stopzetting een disproportionele maatregel vormde die aanleiding gaf tot een schending van artikel I PI.

44. Het discriminatieverbod, dat zowel in artikel E van het ESH als in artikel I4 EVRM en Protocol $n^{\circ}$ I2 is vastgelegd, biedt misschien wel het meest mogelijkheden om sociale en economische grondrechten onder de rechtsmacht van het EHRM te brengen. Artikel I4 EVRM verbiedt echter enkel discriminaties in het genot van de rechten en vrijheden opgesomd in het EVRM. Het is dus enkel indien bepaalde feiten onder het toepassingsgebied van een burgerlijk of politiek recht vallen, dat een beroep kan worden gedaan op artikel I4 EVRM. Op die manier is de poort naar sociale en economische rechten nog enigszins gesloten, al kan er via het recht op eigendom al veel bereikt worden. ${ }^{210}$ Protocol $n^{\circ} 12$ voert daarentegen een algemeen discriminatieverbod in, dat los staat van de in het EVRM gewaarborgde rechten en vrijheden. Dit zou betekenen dat ook elke mogelijke discriminatie die onder het toepassingsgebied valt van sociale en economische grondrechten onder de rechtsmacht van het EHRM zou vallen. Dit verklaart misschien de terughoudendheid van vele staten, waaronder België, ${ }^{21 I}$ om dit protocol te ratificeren. De Belgische overheden zijn zich alvast op basis van de rechtspraak van het voormalige Arbitragehof goed bewust van de mogelijkheden om via het discrimintieverbod ook aan andere grondrechten te toetsen.

208 EHRM, Meyne-Moskalczuk, beslissing van 9 december 2003, <www.echr.coe.int>; EHRM, Grote Kamer, Carson t. Verenigd Koninkrijk van i6 maart 20Io, Reports 2010.

209 Zie recent bijvoorbeeld EHRM, Khoniakina t. Georgië, arrest van I9 juni 2012 (over de vermindering van het pensioen van magistraten).

2Io Zie ook EHRM, Gaygusuz t. Oostenrijk, arrest van I6 september I996, Reports I996-IV (i.v.m. de weigering om 'bijstand in spoedgevallen' toe te kennen aan een vreemdeling die anders voldeed aan de voorwaarden) en EHRM, Koua Poirrez t. Frankrijk, arrest van 30 september 2003, Reports 2003-X (i.v.m. de weigering om de bijstand aan mindervaliden toe te kennen). In beide gevallen besluit het EHRM in een schending van artikel I4 EVRM in combinatie met artikel I PI omwille van een discriminatie op grond van nationaliteit. In EHRM, Grote Kamer, Stec t. Verenigd Koninkrijk, arrest van 12 april 2006, Reports 2006-VI werd geen schending vastgesteld (\$66): 'the Court finds that the difference in State pensionable age between men and women in the United Kingdom was originally intended to correct the disadvantaged economic position of women. It continued to be reasonably and objectively justified on this ground until such time as social and economic changes removed the need for special treatment for women. The respondent State's decisions as to the precise timing and means of putting right the inequality were not so manifestly unreasonable as to exceed the wide margin of appreciation allowed it in such a field (see paragraph 52 above). Similarly, the decision to link eligibility for REA to the pension system was reasonably and objectively justified, given that this benefit is intended to compensate for reduced earning capacity during a person's working life. There has not, therefore, been a violation of Article I4 of the Convention taken in conjunction with Article I of Protocol No. I in this case.' Er wordt evenmin een schending vastgesteld in EHRM, Grote Kamer, Carson t. Verenigd Koninkrijk, arrest van I6 maart 20I0, Reports 2010.

2 II België heeft Protocol nr. I2 wel ondertekend in 2000. Nederland heeft het Protocol geratificeerd en het is voor Nederland in werking sinds I april 2005. 


\section{Besluit}

45. In dit artikel hebben we onderzocht welke de juridische grenzen zijn waaraan een herijking van de welvaartsstaat moet voldoen.

Die grenzen worden eigenlijk al aangegeven in Deleeck's definitie van het begrip welvaartsstaat. Zij 'voorziet de effectieve waarborg, aan alle burgers van grondrechten strekkende tot de minimale deelname aan de welvaart en tot behoeftedekking op gebied van inkomen, onderwijs, gezondheid huisvesting en cultuur.'212 Dit artikel onderzocht de Belgische en in mindere mate Europese adviespraktijk en rechtspraak om te begrijpen wat dit in de praktijk betekent.

Een eerste conclusie is dat sociale en economische grondrechten op nog heel wat juridische weerstand botsen. Vaak wordt geopperd dat de Staten geen subjectieve rechten hebben willen toekennen. De draagwijdte van deze grondrechten zou ook onvoldoende duidelijk en precies zijn om toepasbaar te zijn door de rechter. De adviespraktijk en rechtspraak van het Grondwettelijk Hof en de Raad van State toont evenwel aan dat deze grondrechten vaak voldoende duidelijk en precies zijn om toegepast te worden in het objectief contentieux, waar de vraag of de staat subjectieve rechten wilde toekennen niet aan de orde is. Ook andere rechters, zij het voorlopig nog een minderheid, sluiten zich aan bij de vaststelling dat sociale en economische rechten voldoende precies zijn om juridisch afgedwongen te worden.

Ten tweede kan vastgesteld worden dat het onderscheid tussen positieve en negatieve plichten nog vaak gehanteerd wordt en cruciaal is om de draagwijdte van sociale en economische rechten te begrijpen. De Raad van State en het Grondwettelijk Hof lijken alvast in bepaalde arresten aan te geven dat de negatieve verplichtingen van artikel 23 van de Grondwet voldoende duidelijk zijn om rechtstreeks toegepast te worden. Beide hoge rechtscolleges onderzoeken dan of een maatregel van de overheid de economische of sociale grondrechten inperkt zonder dat daarvoor een geschikte rechtvaardiging voor gevonden kan worden. De erkenning van positieve verplichtingen ligt dan weer heel wat moeilijker. De rechters lijken zich bewust van het gevaar om te actief op te treden en de plaats van de wetgever in te nemen. Om aan dit bezwaar tegemoet te komen, wordt in de rechtsleer en rechtspraak vaak een beroep gedaan op het standstill-beginsel. Het is de wetgever verboden om het sociale beschermingsniveau aanzienlijk te verminderen zonder dat daartoe redenen van algemeen belang bestaan. Op die manier lijkt men minstens de verplichtingen van de staat op een bepaald niveau te kunnen betonneren.

Een derde conclusie is echter dat het standstill-beginsel bijzonder weinig impact heeft in sociale materies en weinig meerwaarde biedt. Het Grondwettelijk Hof heeft nog nooit een schending van dit beginsel vastgesteld in sociale zaken en de Raad

2 I2 H. Deleeck, De Architectuur van de welvaartsstaat opnieuw bekeken, Leuven, Acco, 2008, 32. 
van State, afdeling bestuurrechtspraak, heeft in het arrest Coomans de beperkte relevantie van dit beginsel aangegeven. Ook de Raad van State, afdeling wetgeving, is nogal terughoudend om het standstill-beginsel toe te passen. Eigenlijk is het standstill-beginsel een afgezwakte versie van de proportionaliteitstoets die traditioneel gemaakt wordt bij andere grondrechten. Het is onze overtuiging dat deze tussenstap, die afwijkt van de traditionele benadering inzake positieve verplichtingen, overbodig is. Om na te gaan of een staat een positieve verplichting heeft, volstaat het om na te gaan of er een billijk evenwicht is tussen de rechten van het individu op een sociale en economische bescherming en het algemeen belang, rekening houdend met de plichten die het individu heeft om zelf inspanningen te doen om zijn welvaart te behouden. ${ }^{213}$ Het uitgangspunt daarbij is dat de wetgever over een ruime appreciatiemarge beschikt om na te gaan welke maatregelen aangewezen zijn. Het is slechts voor zover de menselijke waardigheid in het gedrang dreigt te komen dat de rechter kan optreden om de wetgever op zijn taak te wijzen en positieve verplichtingen op te leggen. Het Grondwettelijk Hof heeft in zijn rechtspraak met betrekking tot artikel 23 van de Grondwet veelvuldig aangegeven dat het het oordeel van de wetgever met betrekking tot het algemeen belang dient te eerbiedigen, tenzij dat oordeel kennelijk onredelijk is.

Dit brengt ons bij een vierde vaststelling: de beoordelingsvrijheid van de wetgever wordt minder ruim wanneer bepaalde kwetsbare groepen geviseerd worden. Zowel in de rechtspraak van het Grondwettelijk Hof, van het EVRM als die van het ESC wordt veelvuldig gebruik gemaakt van het gelijkheidsbeginsel om de overheid te wijzen op haar positieve plicht om ook de zwakkere groepen in de samenleving dezelfde sociale en economische grondrechten te garanderen. Iedereen, zowel de asielzoeker, de Roma-zigeuner als de sociale huurder, heeft het recht op een menswaardig leven. Dit betekent vaak dat men ook effectief over dezelfde rechten dient te beschikken als zijn medeburger. Dit is niet altijd eenvoudig te realiseren, maar de staat zal zoals het ESC in Fensea aangeeft, moeten aantonen dat het alles doet om een meetbare vooruitgang te boeken. Hiermee wordt mijn inziens ook het evolutieve karakter van sociale en economische grondrechten benadrukt.

De belangrijkste bevinding is misschien wel dat sociale en economische grondrechten dienen om ieder een menswaardig leven te garanderen. ${ }^{214}$ Deze rechten garanderen aldus een minimumbescherming waaronder de wetgever niet kan duiken. Dit betekent evenwel niet dat deze rechten absoluut zijn. De rechter zal zich steeds de vraag moeten stellen of (het ontbreken van) een maatregel evenredig is in het licht van het doel dat de overheid wenst te bereiken. Daarbij zal hij ook rekening dienen te houden met de middelen waarover de overheid beschikt en de plichten

2I3 Die verplichtingen moeten de personen aan wie zij worden opgelegd, in staat stellen bij te dragen tot de effectieve verwezenlijking van een menswaardig leven voor eenieder, en moeten evenredig zijn met de aldus bepaalde doelstelling.

2I4 Artikel 23 van de Grondwet: 'Ieder heeft het recht een menswaardig leven te leiden. Daartoe waarborgen de wet (...).' 
van het individu. Dezelfde vraag is aan de orde bij het onderzoek of burgerlijke of politieke rechten geschonden zijn. Hiermee lijkt men te moeten concluderen dat het onderscheid tussen sociale en economische rechten enerzijds en burgerlijke en politieke rechten anderzijds enigszins artificieel is. Het belangrijkste verschil zit hem eigenlijk vooral op procedureel vlak, waar de rechterlijke controle zowel op internationaal $^{215}$ als nationaal ${ }^{216}$ vlak minder stringent is. Een meer geïntegreerde aanpak is aangewezen. De rechtspraak van het EHRM lijkt ook in die zin te evolueren.

Ten slotte dient benadrukt te worden dat er ook procedurele rechtswaarborgen zijn. Bij een heroriëntering van de welvaartsstaat zal de medewerking van de erkende vrije sociale organisaties in het raam van instellingen van overleg cruciaal zijn. Het is ook aan de parlementaire democratie om te beslissen welke wijzigingen doorgevoerd dienen te worden. Het is in die optiek dat het belang van het legaliteitsbeginsel, dat voortvloeit uit artikel 23 van de Grondwet, niet onderschat mag worden. Het is aan het parlement om de richting aan te geven en te beslissen. De magistraten kunnen en mogen daarbij enkel nagaan of er geen ongerechtvaardigde aantasting is van grondrechten die de menselijke waardigheid in het gedrang dreigt te brengen. De menselijke waardigheid en respect voor de wetgevende macht zijn het kompas waar de nationale en Europese rechter op moeten varen. Indien de democratische legitimiteit van de beslissingen minder groot is, zal de controle van de rechter strikter moeten zijn. ${ }^{217}$

Dit alles doet de vraag rijzen of de grondrechten ook een effectieve en voldoende waarborg bieden voor de welvaartsstaat. Op basis van de geanalyseerde rechtspraak kan men besluiten dat er voldoende rechtswaarborgen zijn tegen een ontmanteling van de welvaartsstaat. Er is in België evenwel geen sprake van ontmanteling, maar wel van aanpassing en heroriëntering. ${ }^{218}$ Dit zorgt ervoor dat er vaak een complexe belangenafweging vereist is. Rechters dienen hierbij enige bescheidenheid aan de dag te leggen. In principe is de wetgever beter geplaatst om een dergelijke afweging te maken. Het is pas wanneer de menselijke waardigheid in het gedrang dreigt te komen, dat de rechter de wetgever kan terugfluiten of aanmanen om op te treden.

46. Tot slot nog dit. Bij het lezen van dit besluit zou men met een enigszins onvoldaan gevoel kunnen blijven zitten. De inhoudelijke draagwijdte van de rechtsbescherming is slechts sporadisch aan bod gekomen. Dit is het gevolg van onze casuïstische benadering. Het is evenwel onze overtuiging dat een precieze en allesomvattende inhoudelijke omschrijving van alle materiële rechten onmogelijk is. Mensenrechtennormen zijn immers open normen en dit betekent dat niet alles in detail in het artikel beschreven moet worden, maar dat het doel en het voorwerp ('object and purpose') van de norm vastgelegd is. Het is aan de rechtspraak om in

2I5 Het ESH-Comité velt geen bindende arresten zoals het EHRM (zie supra).

2I6 Hierbij kan verwezen worden naar de discussie over de rechtstreekse werking.

217 EHRM, GK, Bosphorus t. Ierland, arrest van 30 juni 2005.

2 I8 H. Deleeck, De Architectuur van de welvaartsstaat opnieuw bekeken, Leuven, Acco, 2008, 90. 
concrete gevallen invulling te geven aan deze open normen zonder de prerogatieven van de wetgevende of uitvoerende macht uit het oog te verliezen. De effectieve verwezenlijking en handhaving van grondwettelijk en verdragsrechterlijk gewaarborgde grondrechten, een noodzakelijke voorwaarde om van een welvaartsstaat te kunnen spreken, zal altijd een delicate evenwichtsoefening blijven. 